OPEN ACCESS

Edited by:

Marcus A. Horn

Leibniz Universität Hannover,

Germany

Reviewed by:

Oliver Schmidt,

University of Bayreuth, Germany

Steffen Kolb,

Leibniz-Zentrum für

Agrarlandschaftsforschung (ZALF),

Germany

*Correspondence:

Svetlana N. Dedysh dedysh@mail.ru

Specialty section: This article was submitted to Terrestrial Microbiology, a section of the journal

Frontiers in Microbiology

Received: 25 August 2018

Accepted: 29 October 2018

Published: 19 November 2018

Citation:

Belova SE, Ravin NV,

Pankratov TA, Rakitin AL, Ivanova AA Beletsky AV, Mardanov AV, Sinninghe Damsté JS and Dedysh SN (2018)

Hydrolytic Capabilities as a Key

to Environmental Success: Chitinolytic and Cellulolytic Acidobacteria From Acidic Sub-arctic Soils and Boreal

Peatlands. Front. Microbiol. 9:2775. doi: 10.3389/fmicb.2018.02775

\section{Hydrolytic Capabilities as a Key to Environmental Success: Chitinolytic and Cellulolytic Acidobacteria From Acidic Sub-arctic Soils and Boreal Peatlands}

\author{
Svetlana E. Belova1, Nikolai V. Ravin², Timofey A. Pankratov³, Andrey L. Rakitin², \\ Anastasia A. Ivanova', Alexey V. Beletsky², Andrey V. Mardanov², \\ Jaap S. Sinninghe Damstét, ${ }^{4}$ and Svetlana N. Dedysh ${ }^{1 *}$ \\ ${ }^{1}$ Winogradsky Institute of Microbiology, Research Center of Biotechnology of the Russian Academy of Sciences, Moscow, \\ Russia, ${ }^{2}$ Institute of Bioengineering, Research Center of Biotechnology of the Russian Academy of Sciences, Moscow, \\ Russia, ${ }^{3}$ M.V. Lomonosov Moscow State University, Moscow, Russia, ${ }^{4}$ Department of Marine Microbiology \\ and Biogeochemistry, Royal Netherlands Institute for Sea Research, Utrecht University, Den Burg, Netherlands, \\ ${ }^{5}$ Geochemistry, Department of Earth Sciences, Faculty of Geosciences, Utrecht University, Utrecht, Netherlands
}

Members of the Acidobacteria are among the most efficient colonizers of acidic terrestrial habitats but the key traits underlying their environmental fitness remain to be understood. We analyzed indigenous assemblages of Acidobacteria in a lichencovered acidic $(\mathrm{pH} 4.1)$ soil of forested tundra dominated by uncultivated members of subdivision 1. An isolate of these bacteria with cells occurring within saccular chambers, strain $\mathrm{SBC}^{\top}{ }^{\top}$, was obtained. The genome of strain $\mathrm{SBC}^{\top} 2^{\top}$ consists of a $7.11-\mathrm{Mb}$ chromosome and four megaplasmids, and encodes a wide repertoire of enzymes involved in degradation of chitin, cellulose, and xylan. Among those, four secreted chitinases affiliated with the glycoside hydrolase family GH18 were identified. Strain SBC82 ${ }^{\top}$ utilized amorphous chitin as a source of carbon and nitrogen; the respective enzyme activities were detected in tests with synthetic substrates. Chitinolytic capability was also confirmed for another phylogenetically related acidobacterium isolated from a Sphagnum peat bog, strain $\mathrm{CCO} 287$. As revealed by metatranscriptomic analysis of chitin-amended peat, 16S rRNA reads from these acidobacteria increased in response to chitin availability. Strains $\mathrm{SBC} 82^{\top}$ and $\mathrm{CCO} 287$ were assigned to a novel genus and species, Acidisarcina polymorpha gen. nov., sp. nov. Members of this genus colonize acidic soils and peatlands and specialize in degrading complex polysaccharides.

Keywords: Acidobacteria, Acidisarcina, lichen-covered tundra, genome annotation, chitinase, chitinolytic ability

\section{INTRODUCTION}

Members of the phylum Acidobacteria inhabit a wide variety of terrestrial and aquatic ecosystems (Ludwig et al., 1997; Barns et al., 1999; Kielak et al., 2016; Dedysh and Sinninghe Damsté, 2018; Eichorst et al., 2018). As judged by the proportion of Acidobacteria-affiliated 16S rRNA and 16S rRNA gene reads in sequence pools retrieved from different environments, these bacteria are 
particularly abundant in diverse soil habitats, where they represent between 5 and $50 \%$ of the total bacterial community (Janssen, 2006; Lee et al., 2008; Jones et al., 2009; Lauber et al., 2009; Foesel et al., 2014). The highest relative abundances of Acidobacteria are commonly observed in acidic soils and peatlands, which are dominated by representatives of subdivisions (Sd) 1 and 3 of this phylum (Jones et al., 2009; Lauber et al., 2009; Serkebaeva et al., 2013).

The reasons behind this high environmental fitness of soil Acidobacteria are only partly understood. The first analysis of three genomes from representatives of Sds 1 and 3, i.e., Acidobacterium capsulatum, 'Koribacter versatilis' and 'Solibacter usitatus,' revealed their potential to participate in the cycling of plant-, fungal-, and insect-derived organic matter (Ward et al., 2009). The genomes encode a wide repertoire of enzymes involved in breakdown and utilization of a diverse suite of carbohydrates. Further genome analyses were also supportive for placing the Acidobacteria in the list of organisms involved in hydrolysis and utilization of various biopolymers in nature (Rawat et al., 2012; Kielak et al., 2016). Additional arguments in support of the hydrolytic capabilities of Acidobacteria were obtained in a number of cultivation-independent studies. Incubation experiments with ${ }^{13} \mathrm{C}$-labeled cellulose revealed Acidobacteria among aerobic decomposers of this biopolymer in an acidic forest soil (Štursová et al., 2012). Several other studies identified members of the family Acidobacteriaceae among the anaerobic microorganisms that process cellulose-derived carbon in acidic peatlands (Schmidt et al., 2014; Juottonen et al., 2017). Finally, a specific response to chitin availability was detected for Sd1 Acidobacteria in a metatranscriptome-based study with acidic peat (Ivanova et al., 2016).

By contrast, experimental evidence for the hydrolytic capabilities of cultured Acidobacteria is rare. Two acidobacterial isolates from agricultural grassland soils obtained by using a complex medium of plant polymeric carbon, strains KBS 83 and KBS 96, were reported to possess cellulolytic potential, but their capability of degrading cellulose was not demonstrated (Eichorst et al., 2011). The presence of a weak chitinolytic capability was first reported for the $\mathrm{Sd} 4$ acidobacterium, Blastocatella fastidiosa (Foesel et al., 2013) and, later, for two members of Sd1, Terracidiphilus gabretensis (García-Fraile et al., 2015) and Silvibacterium bohemicum (Lladó et al., 2016). The two latter species were described as possessing cellulolytic potential as well. None of these studies, however, reported related enzyme activities or growth dynamics on cellulose or chitin. Solid experimental evidence for the occurrence of cellulolytic potential was presented only for Telmatobacter bradus, which was described as a facultative anaerobe capable of degrading amorphous and crystalline cellulose under micro-oxic and anoxic conditions (Pankratov et al., 2012). The products of cellulose degradation by Telmatobacter under anoxic conditions are acetate and hydrogen. Weak cellulolytic capabilities were also demonstrated for a taxonomically uncharacterized Sd1 acidobacterium, strain CCO287, which was isolated from an acidic Sphagnum peat bog (Pankratov et al., 2011). This isolate possessed specific cell morphology: cells were highly polymorphic and arranged in cluster-like aggregates. Extremely slow growth in liquid media did not allow investigating hydrolytic capabilities of strain CCO287 in more detail.

In the course of our recent work on the diversity of Acidobacteria in lichen-covered soils of forested tundra, we obtained another, phylogenetically related isolate with the same specific morphology as strain CCO287. It showed a more consistent growth allowing a detailed characterization of its physiology and specific adaptations. We also analyzed its genome-encoded traits and hydrolytic capabilities, which reveal the reasons behind wide distribution of these Acidobacteria in acidic soils and peatlands.

\section{MATERIALS AND METHODS}

\section{Study Site and Sampling Procedure}

The study site was located in the Nadym region of northwest Siberia, Yamalo-Nenets AO, Russia, in a pine (Pinus sibirica) forest within a permafrost-free zone of forested tundra $\left(\mathrm{N} 65^{\circ} 36^{\prime} 07.1^{\prime \prime}\right.$, E72 $\left.44^{\prime} 39.5^{\prime \prime}\right)$. The ground vegetation was composed of lichens (Cladonia stellaris, Cladonia alpestris, and Cetraria islandica) with a minor presence of Vaccinium spp., Ledum palustre, and Polytrichum commune (Figure 1a). Three individual plots, at a distance of $15-20 \mathrm{~m}$ from each other, were chosen for sampling purposes. The soil samples (ca. $500 \mathrm{~g}$ each) were collected from the surface (1-5 cm depth) organic soil layer $(\mathrm{pH} 4.1)$ underlying the lichen cover. The samples were transported to the laboratory in boxes containing ice packs, homogenized, and frozen at $-20^{\circ} \mathrm{C}$ for DNA extraction within 1 day after sampling.

\section{High-Throughput Sequencing of 16S rRNA Genes}

Three individual soil samples obtained from three different plots, each of $0.5 \mathrm{~g}$ wet weight, were taken for the analysis and processed separately. Isolation of total DNA from soil samples was performed using FastDNA SPIN kit for soil (MP Biomedicals, United States) and FastPrep-24 homogenizer (MP Biomedicals, United States) in accordance with manufacturer's instructions. Subsequent purification of DNA samples was performed using preparative gel electrophoresis and Cleanup Standard Kit (Evrogen, Russia). The V4 region of 16S rRNA genes was amplified from the DNA samples using the 515f/806r primer set (Caporaso J.G. et al., 2010) with some primer modifications: as forward primer the Univ515F primer was used ( $5^{\prime}-\mathrm{GTG}$ BCA GCM GCC GCG GTA A-3'; Kublanov et al., 2009). The resulting amplicons were purified by agarose gel electrophoresis using Cleanup Standard Kit (Evrogen, Russia) and sequenced using the 300PE protocol on MiSeq System (Illumina, United States). Resulting reads were subjected to stringent quality filtering and trimming with CLC Genomics Workbench 7.5 (Qiagen, Germany). After filtering, overlapping paired-end library reads were merged with SeqPrep tool ${ }^{1}$. Demultiplexing and further processing of the resulting data set was carried out using QIIME v.1.8. package (Caporaso J. et al., 2010). Taxonomic assignment

\footnotetext{
${ }^{1}$ https://github.com/jstjohn/SeqPrep
} 

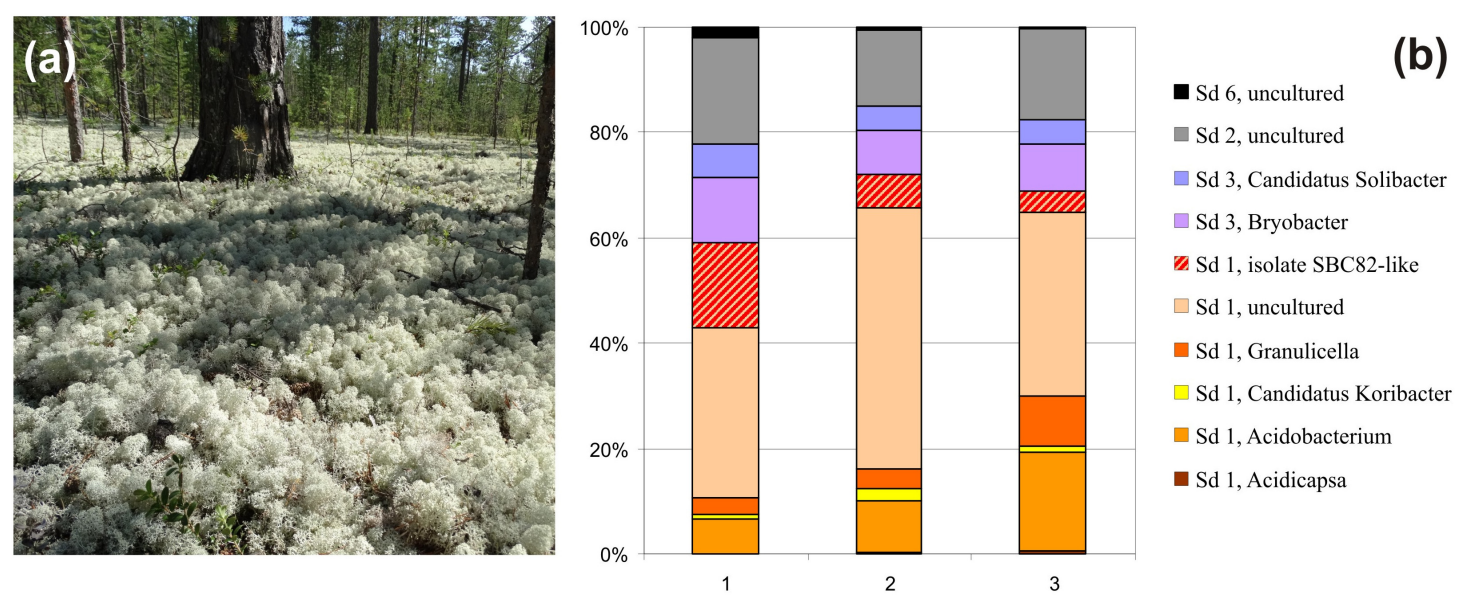

FIGURE 1 | (a) The forested tundra site examined in this study: pine forest with ground vegetation cover composed of reindeer lichens. (b) Community composition of the Acidobacteria within three individual plots of the forested tundra based on Illumina paired-end sequencing of $16 \mathrm{~S}$ rRNA gene fragments. The proportion of reads assigned to isolate SBS82-like bacteria was determined based on the sequence identity threshold of $97 \%$.

was performed using RDP classifier retrained with Silva 128 database (Pruesse et al., 2007; Quast et al., 2013). Culling of chimeric sequences was performed using ChimeraSlayer algorithm (Grabherr et al., 2011).

\section{Cultivation Studies}

Ten grams of a surface soil enriched with decomposed thalli of Cladonia sp. were grinded in a mortar and the resulting material was suspended in $50 \mathrm{ml}$ of sterile water. This suspension was further diluted (1:50) and spread-plated onto the medium solidified with $9 \mathrm{~g}$ phytagel (Sigma-Aldrich) and containing (per liter distilled water): $0.25 \mathrm{~g}$ xylan, $0.25 \mathrm{~g}$ starch, $0.05 \mathrm{~g}$ Bacto Tryptic Soy Broth without Dextrose, $0.1 \mathrm{~g} \mathrm{NH}_{4} \mathrm{NO}_{3}, 0.1 \mathrm{~g}$ $\mathrm{MgSO}_{4} \cdot 7 \mathrm{H}_{2} \mathrm{O}, 0.04 \mathrm{~g} \mathrm{KH}_{2} \mathrm{PO}_{4} ; \mathrm{pH}$ was adjusted to 4.5 with $30 \mathrm{mg}$ alginic acid $\mathrm{l}^{-1}$. The plates were incubated at $20^{\circ} \mathrm{C}$ for 4 weeks. Colonies that developed on these plates were screened using the Acidobacteria-specific PCR approach (Stevenson et al., 2004). One particular type of colonies that were identified as belonging to members of the Acidobacteria was represented by small (1-3 mm in diameter after 4 weeks of incubation), gummy consistency, opal-beige to light pink in color, circular colonies. Cell material from these colonies was further re-streaked on the above described medium and the plates were incubated under the same conditions until the target bacterium, designated strain $\mathrm{SBC} 82^{\mathrm{T}}$, was obtained as a pure culture. Strain $\mathrm{SBC} 82^{\mathrm{T}}$ was maintained on the solid medium MA containing (per liter distilled water): $0.5 \mathrm{~g}$ fructose, $0.1 \mathrm{~g}$ yeast extract, $0.04 \mathrm{~g}$ $\mathrm{MgSO}_{4} \cdot 7 \mathrm{H}_{2} \mathrm{O}, 0.04 \mathrm{~g} \mathrm{KH}_{2} \mathrm{PO}_{4}, 0.02 \mathrm{~g} \mathrm{CaCl}_{2} \cdot 2 \mathrm{H}_{2} \mathrm{O}, 0.2 \mathrm{~g} \mathrm{KNO}$, $9 \mathrm{~g}$ phytagel, $0.03 \mathrm{~g}$ alginic acid, $\mathrm{pH} 4.6-5.0$ and was sub-cultured at 3-week-intervals.

The isolation and brief characterization of strain CCO287 was reported earlier (Pankratov et al., 2011). This bacterium was isolated from Sphagnum-derived peat collected from the ombrotrophic peat bog Obukhovskoye, Yaroslavl region, European North Russia $\left(58^{\circ} 14^{\prime} \mathrm{N}, 38^{\circ} 12^{\prime} \mathrm{E}\right)$ by means of plating onto an acidic ( $\mathrm{pH} 4.5-5.0)$ medium with cellulose powder
(Aldrich). Strain CCO287 was maintained on the medium MA supplied with $2 \mathrm{ml}$ vitamin solution of the following composition (g per $100 \mathrm{ml}$ distilled water): $\mathrm{p}$-aminobenzoate, 1.0; biotin, 0.2; nicotinic acid, 2.0; thiamine- $\mathrm{HCl} \times 2 \mathrm{H}_{2} \mathrm{O}, 1.0$; Ca-pantothenate, 0.5; pyridoxamine, 5.0; vitamin $\mathrm{B} 12,2.0$.

\section{Microscopy}

Morphological observations and cell size measurements were made with a Zeiss Axioplan 2 microscope and Axiovision 4.2 software (Zeiss, Germany). For preparation of ultrathin sections, cells of the exponentially growing culture were collected by centrifugation and pre-fixed with $1.5 \%(\mathrm{w} / \mathrm{v})$ glutaraldehyde in $0.05 \mathrm{M}$ cacodylate buffer ( $\mathrm{pH}$ 6.5) for $1 \mathrm{~h}$ at $4^{\circ} \mathrm{C}$ and then fixed with $1 \%(\mathrm{w} / \mathrm{v}) \mathrm{OsO}_{4}$ in the same buffer for $4 \mathrm{~h}$ at $20^{\circ} \mathrm{C}$. After dehydration in an ethanol series, the samples were embedded into Epon 812 epoxy resin. Thin sections were cut on an LKB4800 microtome, stained with 3\% (w/v) uranyl acetate in $70 \%$ (v/v) ethanol, and then were stained with lead citrate (Reynolds, $1963)$ at $20^{\circ} \mathrm{C}$ for $4-5 \mathrm{~min}$. The specimen samples were examined with JEM-1011 (JEOL, Japan) transmission electron microscope.

\section{Chemotaxonomic Analyses}

For the analysis of total lipids (including fatty acids), cells of strains $\mathrm{SBC} 82^{\mathrm{T}}$ and $\mathrm{CCO} 287$ were grown in liquid medium MA and harvested in the late exponential growth phase. Lipids were analyzed after acid hydrolysis of the cell material following the procedure described by Sinninghe Damsté et al. (2011). The intact polar lipids (IPLs) in these bacteria were analyzed as described by Moore et al. (2013).

Isoprenoid quinones were extracted according to Collins (1985) and analyzed using a tandem-type mass spectrometer LCQ ADVANTAGE MAX and a Finnigan Mat 8430 ionization mass spectrometer with atmospheric pressure chemical ionization (APCI). 


\section{Phenotypic Characterization}

Physiological tests were performed using batch cultures grown in the liquid medium MA without phytagel. Growth of strain $\mathrm{SBC} 82^{\mathrm{T}}$ was monitored by nephelometry at $410 \mathrm{~nm}$ using "Specol" spectrophotometer (Carl Zeiss) for 14 days under a variety of conditions, including temperatures of $2-37^{\circ} \mathrm{C}, \mathrm{pH}$ $3.0-7.9$ and $\mathrm{NaCl}$ concentrations of $0-4.0 \%(\mathrm{w} / \mathrm{v})$. Incubations at various temperatures were made under static conditions in triplicate. Variations in $\mathrm{pH}$ were achieved by using MES ( $\mathrm{pH} 4.0-$ 6.5) and MOPS (pH 6.5-7.9) buffer systems. The $\mathrm{pH}$ range of 3-4 was achieved by adjusting the medium $\mathrm{pH}$ with $0.1 \mathrm{M} \mathrm{H}_{2} \mathrm{SO}_{4}$. The range of potential growth substrates of strain $\mathrm{SBC} 82^{\mathrm{T}}$ was examined on liquid medium MA by replacing fructose with respective carbon sources $(0.05 \%[\mathrm{w} / \mathrm{v}])$ and decreasing the concentration of yeast extract to $0.005 \%(\mathrm{w} / \mathrm{v})$. Cultivation was done in $30 \mathrm{ml}$ vials containing $5 \mathrm{ml}$ medium. The inoculated cells were washed with a fresh medium without any substrate before a new batch culture was inoculated. The incubations were kept at $22^{\circ} \mathrm{C}$ for 3 weeks on a shaker. All experiments were performed in triplicate. Enzymatic profiles, urease, $\beta$-galactosidase activity, indole production, abilities to hydrolyze gelatin and esculin were examined with API ZYM and API 20NE kits (bioMérieux). A catalase test was carried out by using the standard method (Gerhardt, 1981). Oxidase was tested using a REF 55635 Oxidase Reagent (bioMérieux). The ability to grow under anaerobic conditions was tested in anaerobic jars by using AnaeroGen anaerobic system envelopes (Oxoid), which absorb atmospheric oxygen with the simultaneous generation of $\mathrm{CO}_{2}$ (up to $9-13 \%$, $\mathrm{vol} / \mathrm{vol})$.

\section{Growth Experiments and Whole-Cell Hybridization}

Strain $\mathrm{SBC} 82^{\mathrm{T}}$ was grown under static conditions at $25^{\circ} \mathrm{C}$ in $160 \mathrm{ml}$ serum bottles containing $20 \mathrm{ml}$ of liquid medium MA without fructose. Amorphous chitin was prepared as described elsewhere (Sorokin et al., 2014) and added to the medium at a concentration of $0.1 \%(\mathrm{w} / \mathrm{v})$. In one set of experimental flasks, chitin was provided as a sole source of carbon, while $\mathrm{KNO}_{3}(0.02 \%$, w/v) was supplied as a chitin-independent source of nitrogen. In the second set of incubation flasks, chitin was added as the sole source of carbon and nitrogen, while $\mathrm{KNO}_{3}$ was omitted from the medium composition. Control incubations without chitin were run in parallel under the same conditions. All incubations were performed in triplicate. After 20 days of incubation, the culture suspensions were fixed with $4 \%$ (wt/vol) freshly prepared paraformaldehyde solution as described by Dedysh et al. (2001). The Acidobacteriaspecific Cy3-labeled oligonucleotide probe HoAc1402 (5'CTTTCGTGATGTGACGGG-3') (Juretschko et al., 2002) was applied for specific detection of cells on micro-particles of chitin. The oligonucleotide probe was purchased from Syntol (Moscow, Russia). Hybridization was done on gelatin-coated $(0.1 \%$, wt $/ \mathrm{vol})$ and dried Teflon-laminated slides (MAGV, Germany) with eight wells for independent positioning of the samples. The fixed samples were applied to these wells, hybridized to the corresponding fluorescent probes, and stained with the universal
DNA stain 4',6-diamidino-2-phenylindole (DAPI, $1 \mu \mathrm{M}$ ). Cell counts were carried out with a Zeiss Axioplan 2 microscope (Zeiss, Jena, Germany) equipped with the Zeiss Filters No 20 and 02 for Cy3-labeled probes and DAPI staining, respectively. Cell counting was performed on 100 randomly chosen fields of view (FOV) for each test sample. The number of target cells per $\mathrm{ml}$ of culture suspension was determined from the area of the sample spot, the FOV area, and the volume of the fixed aliquot used for hybridization.

\section{Hydrolytic Activity Assays}

Cells of strain $\mathrm{SBC}^{2 \mathrm{~T}}$ grown in the liquid medium $\mathrm{MA}$ supplemented with $0.1 \%(\mathrm{w} / \mathrm{v})$ amorphous chitin instead of fructose were collected by centrifugation and lysed by sonication. Chitinolytic activities of the resulting cell extracts were measured in a fluorimetric assay with 4-methylumbelliferyl (4-MU) derivatives using a Chitinase Assay Kit (Sigma, CS1030). The following substrates were used: 4-MU- $\beta-\mathrm{D}-\mathrm{N}, \mathrm{N}^{\prime}, \mathrm{N}^{\prime \prime}-$ triacetylchitotriose, $4-\mathrm{MU}$-diacetyl- $\beta$-D-chitobioside and 4-MU$N$-acetyl- $\beta$-D-glucosaminide. One unit of activity was defined as the amount of enzyme required to release $1 \mathrm{nmol}$ of $4-\mathrm{MU}$ from the appropriate substrate per minute. Assays were performed at $25^{\circ} \mathrm{C}$ in $50 \mathrm{mM}$ sodium citrate buffer ( $\mathrm{pH}$ 5.0). The fluorescence of liberated $4 \mathrm{MU}$ was measured using the fluorimeter Fluorat02-Panorama (Lumex, Russian Federation), with excitation at $360 \mathrm{~nm}$ and emission at $450 \mathrm{~nm}$.

\section{Genome Sequencing, Annotation, and Analysis}

For genome analysis, strain $\mathrm{SBC} 82^{\mathrm{T}}$ was grown in shaking liquid cultures at $25^{\circ} \mathrm{C}$ in medium MA. After 3 weeks of incubation, the biomass was collected and used for DNA extraction, library preparation, and sequencing. Genomic DNA of strain $\mathrm{SBC} 82^{\mathrm{T}}$ was sequenced with a Roche Genome Sequencer (GS FLX), using the Titanium XL+ protocol for a shotgun genome library and MinION (Oxford Nanopore), using 1D Genomic DNA by ligation protocol. About $244 \mathrm{Mb}$ of sequences with an average read length of $549 \mathrm{nt}$ were generated on GS FLX and de novo assembled into contigs using Newbler Assembler version 2.9 (454 Life Sciences, Branford, CT, United States). 117573 raw MinION reads (about $1.1 \mathrm{~Gb}$ in total) were corrected and trimmed using Canu assembler (Koren et al., 2017). Corrected MinION reads were used to finish draft GS FLX de novo assembly with npScarf software (Cao et al., 2017). GS FLX reads were mapped back to the finished sequence using Bowtie 2 (Langmead and Salzberg, 2012) and the mapping was used to calculate improved consensus sequence by Pilon software (Walker et al., 2014).

Gene search and annotation were performed using the RAST server (Brettin et al., 2015), followed by manual correction by searching the National Center for Biotechnology Information (NCBI) databases. Signal peptides were predicted using Signal P v.4.1 for Gram-negative bacteria ${ }^{2}$. The $\mathrm{N}$-terminal twin-arginine translocation (Tat) signal peptides were predicted using PRED$\mathrm{TAT}^{3}$ and the transmembrane helices with TMHMM Server

${ }^{2} \mathrm{http} / / /$ www.cbs.dtu.dk/services/SignalP/

${ }^{3} \mathrm{http}: / /$ www.compgen.org/tools/PRED-TAT/ 
v. $2.0^{4}$. The values of DNA-DNA hybridization in silico were calculated using GGDC 2 (Meier-Kolthoff et al., 2013), available at http://ggdc.dsmz.de/, according to formula 1 .

\section{Analysis of Metatranscriptome-Derived Data}

The SSU rRNA dataset retrieved in the study of Ivanova et al. (2016) was used to analyze the abundance of Acidisarcina polymorpha-like acidobacteria in Sphagnum-derived peat and the substrate-induced response of these bacteria to amendments with different biopolymers. The 16S rRNA gene sequences of A. polymorpha strains $\mathrm{SBC} 82^{\mathrm{T}}$ and $\mathrm{CCO} 287$ were used as queries for blastn search via blast+ (Camacho et al., 2009) among the SSU rRNA reads with an identity thresholds of 95 and $99 \%$. Oneway ANOVA followed by Dunnett's multiple comparisons test (i.e., comparison of the results obtained for biopolymer-amended samples with those of the control samples) was performed using GraphPad Prism version 6.00 for Windows, GraphPad Software, La Jolla, CA, United States. ${ }^{5}$. Tests were considered significant if they had a $P$-value $<0.05$.

\section{Sequence Accession Numbers}

The $16 \mathrm{~S}$ rRNA gene reads retrieved using Illumina paired-end sequencing from the forested tundra soil samples (raw data) have been deposited under the Bioproject number PRJNA344855 in the NCBI Sequence Read Archive, with the accession number SAMN05846486. The annotated genome sequence of strain $\mathrm{SBC}^{\mathrm{T}}{ }^{\mathrm{T}}$ has been deposited in GenBank under the accession numbers CP030840-CP030844. The GenBank/EMBL/DDBJ accession numbers for the 16S rRNA gene sequences of strains $\mathrm{SBC} 82^{\mathrm{T}}$ and CCO287 are MH396772 and FR750264, respectively.

\section{RESULTS}

\section{Acidobacteria Diversity in an Acidic Tundra Soil}

A total of 682,752 partial $16 \mathrm{~S}$ rRNA gene sequences (mean amplicon length $253 \mathrm{bp}$ ) were retrieved from the three examined

\footnotetext{
${ }^{4} \mathrm{http} / / /$ www.cbs.dtu.dk/services/TMHMM/

${ }^{5}$ www.graphpad.com
}

soil samples. Of these, 606,366 reads were retained after quality filtering and denoising of the raw data. Only a minor part of these sequences $(0.1-0.4 \%)$ were classified as belonging to the Archaea, more specifically to uncultivated members of the Thaumarchaeota. Major groups of bacteria in lichen covered tundra soil were represented by the Acidobacteria (22-24\% of all classified 16S rRNA gene sequences), Proteobacteria (3340\%), Planctomycetes (13-16\%), Actinobacteria (11-13\%), and Verrucomicrobia (9-10\%).

The pool of 16S rRNA gene fragments assigned to the Acidobacteria included 157,407 reads. Nearly equal numbers of reads $(29,264$ and 36,224$)$ were obtained from samples No 1 and 3 . The number of reads retrieved from sample No 2 was much larger than the others (91,919 reads) and, therefore, $\sim 34,000$ reads were randomly selected from this sequence pool for further analysis (Table 1). The final set of $16 \mathrm{~S}$ rRNA gene fragments from the Acidobacteria used for the analysis included 99,488 reads. The calculated Chaol and Shannon indexes for individual samples were in the range of 837-1,014 and 5.3-5.6, respectively. The number of species-level OTUs determined at $97 \%$ sequence identity ranged between 550 and 685 .

Taxonomic analysis revealed that the surface soil in lichen covered tundra was dominated by Sd1 Acidobacteria (59$71 \%$ of total Acidobacteria-like reads), while Sd2, Sd3 and, to a much lesser extent, Sd6 were also present (14-20, 13-19, and $0-2 \%$, respectively) (Figure 1b). Uncultivated members of the family Acidobacteriaceae were the major fraction of $\mathrm{Sd} 1$ Acidobacteria in these soils (32-49\% of total Acidobacteria-like reads). The sequences affiliated with the genera Acidobacterium and Granulicella comprised two major groups of taxonomically described Sd1 Acidobacteria (7-18 and 3-9\% of total reads, respectively).

\section{Cultivation Studies}

About one hundred of colonies that developed on the acidic (pH 4.5) phytagel-solidified medium with xylan and starch as carbon sources were screened by using the Acidobacteria-specific PCR. Of those, 37 colonies were identified as belonging to members of the phylum Acidobacteria and selected for further analysis. Most of these colonies had a slimy consistency, were light pink to pink in color and were composed of rod-shaped cells. Identification of these isolates by partial $(\sim 600 \mathrm{bp}) 16 \mathrm{~S}$

TABLE 1 | Sequencing statistics and various alpha-diversity metrics for the subset of 16S rRNA gene fragments assigned to the Acidobacteria.

\begin{tabular}{|c|c|c|c|c|c|c|c|c|}
\hline \multirow[t]{2}{*}{ Sample No } & \multirow[t]{2}{*}{ Raw reads } & \multirow{2}{*}{$\begin{array}{l}\text { Filtered } \\
\text { reads* }\end{array}$} & \multirow{2}{*}{$\begin{array}{c}\text { Reads from } \\
\text { Acidobacteria }\end{array}$} & \multicolumn{5}{|c|}{ Diversity indices } \\
\hline & & & & Chao1 & Shannon & $\begin{array}{l}\text { Observed } \\
\text { species** }\end{array}$ & Menhinick & $\begin{array}{l}\text { Good's } \\
\text { coverage } \\
\text { estimator }\end{array}$ \\
\hline 1 & 128,572 & 112,642 & 29264 & 837.8 & 5.4 & 550 & 3.2 & 0.992 \\
\hline
\end{tabular}

number of sequences is given in parentheses for the overrepresented sample 2. 

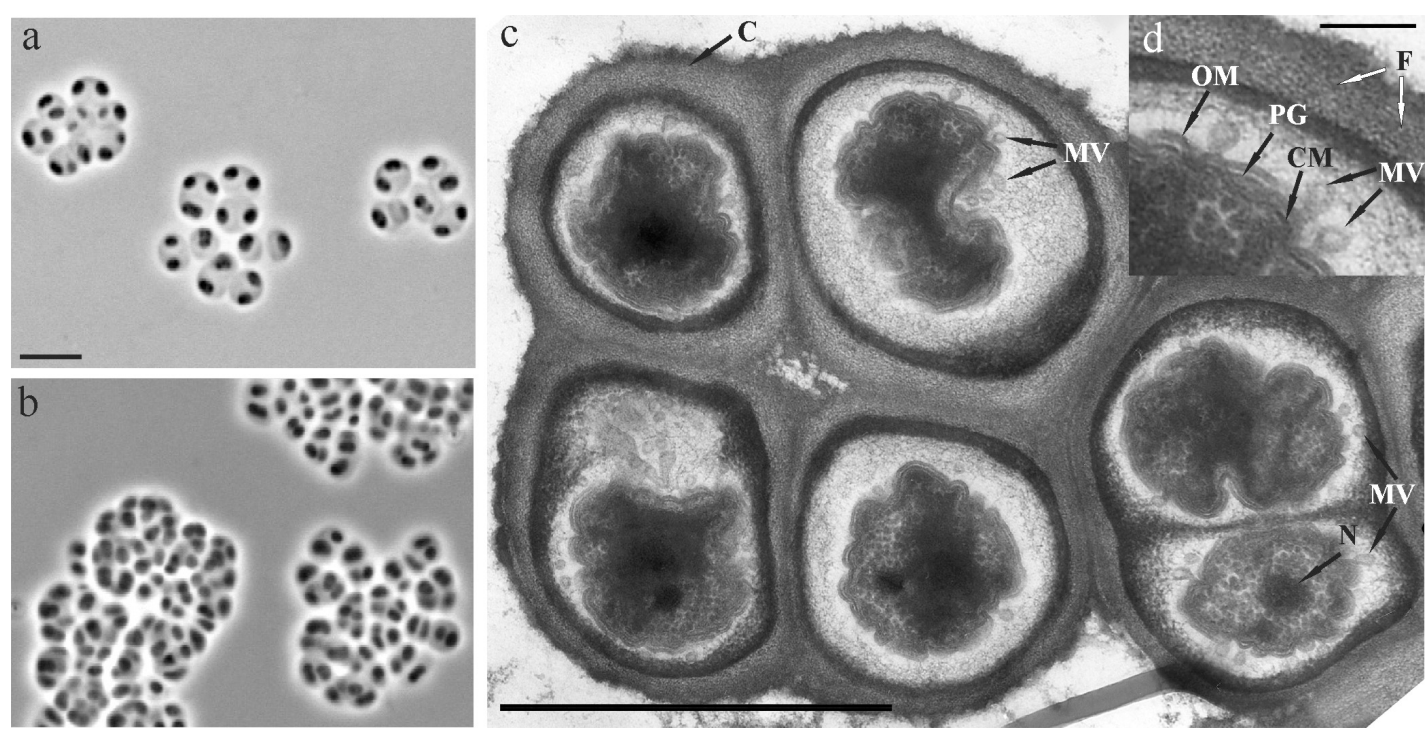

FIGURE 2 | (a,b) Phase-contrast images of cells of strain $\mathrm{SBC}^{\top} 2^{\top}$ grown for 7 days $\mathbf{( a )}$ and 2 weeks (b) in the liquid medium MA supplemented with glucose (a) and xylan (b) as carbon sources. (c) Electron micrograph of an ultrathin section of a cell aggregate from a glucose-grown culture. (d) Enlarged view of outer membrane vesicles formed by invaginations of cytoplasmic membrane. CM, cytoplasmic membrane; OM, outer membrane; PG, peptidoglycan layer; MV, membrane vesicles; N, nucleoid; C, saccular chambers; F, fibril-like structures. Bars, $5 \mu \mathrm{m}$ (a,b), $1 \mu \mathrm{m}$ (c), and $0.1 \mu \mathrm{m}$ (d)

rRNA gene sequencing revealed that they belonged to the genera Granulicella (24 isolates), Terriglobus (1 isolate), Edaphobacter (2 isolates), and Acidicapsa (3 isolates), and displayed 97-99\% $16 \mathrm{~S}$ rRNA gene similarity to described species of these genera. Seven morphologically distinct colonies had gummy consistency, were opal-beige to light pink in color and were composed of polymorphic cells that were arranged in sarcina- or cluster-like aggregates (Figure 2a). This cell morphology was highly similar to that of our earlier described acidobacterial isolate CCO287 from an acidic Sphagnum peat bog (Pankratov et al., 2011). A representative isolate of these bacteria from the lichen-covered tundra soil, strain $\mathrm{SBC} 82^{\mathrm{T}}$, was obtained in a pure culture and was selected for further study. The 16S rRNA gene sequence of strain SBC82 $2^{\mathrm{T}}$ was highly similar $(99.1 \%)$ to that of strain CCO287 but displayed only $92-96 \%$ similarity to 16 S rRNA gene sequences from other currently described members of the family Acidobacteriaceae (Figure 3). The closest phylogenetic relatives of strains $\mathrm{SBC} 82^{\mathrm{T}}$ and $\mathrm{CCO} 287$ were representatives of the genera Acidobacterium, Telmatobacter, Occallatibacter, Terracidiphilus, Acidicapsa, and Acidipila.

\section{Cell Morphology}

Strains $\mathrm{SBC} 82^{\mathrm{T}}$ and CCO287 were non-spore-forming, highly polymorphic bacteria that, most commonly, occurred in pairs, in sarcina-like tetrads, and in clusters of at least six to eight cells (Figures 2a,b). Formation of large and tightly packed cell clusters was observed during growth on polymeric substrates, like xylan (Figure 2b). Single cells or short chains of curved cells could also be observed occasionally. Old cultures contained strongly aggregated cells. Cells were 1.4-4.4 $\mu \mathrm{m}$ long and 0.9-1.5 $\mu \mathrm{m}$ wide. Electron microscopy revealed a cell-wall structure typical of Gram-negative bacteria. The cytoplasmic membrane, peptidoglycan layer and outer membrane were evident in ultrathin sections (Figure 2c). The specific feature of cell morphology of these bacteria was the presence of extracellular structures appearing as saccular chambers of a complex ultrastructure. The chamber envelope was structurally organized by tightly packed fibrils layered in parallel to each other (Figure 2d). This envelope could have been originated from numerous outer membrane vesicles, which were produced by cells, released in the chamber matrix and transferred to the inner surface of the chamber envelope.

\section{Chemotaxonomic Characterization}

In order to taxonomically characterize the two acidobacterial isolates, we analyzed their fatty acid and polar lipid composition. The fatty acid patterns obtained for strains SBC $82^{\mathrm{T}}$ and CCO287 were highly similar and were dominated by 13,16-dimethyl octacosanedioic acid (29.8-30.7\%), iso-C15:0 (24.6-29.4\%),

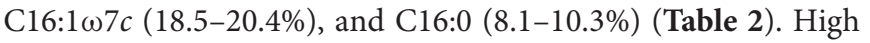
amounts of these fatty acids are commonly found in members of the family Acidobacteriaceae (Sinninghe Damsté et al., 2011). The IPLs in both strains SBC82 $2^{\mathrm{T}}$ and CCO287 were represented by phosphatidylethanolamine (PE), phosphohexose (P-hex) and smaller amounts of an unknown high mass IPL (Table 3). Strain CCO287 contained ornithine lipid (OL) as a major component, while it was present only as a minor component in IPL profile of $\mathrm{SBC} 82^{\mathrm{T}}$. Similar to all currently described members of the family Acidobacteriaceae, strains $\mathrm{SBC} 82^{\mathrm{T}}$ and $\mathrm{CCO} 287$ contained menaquinone-8 (MK-8) as the predominant isoprenoid quinone.

\section{Physiology of Isolates}

Strains SBC82 $2^{\mathrm{T}}$ and $\mathrm{CCO} 287$ were aerobic, acidophilic and psychrotolerant chemoheterotrophs, which grew at $\mathrm{pH}$ values 


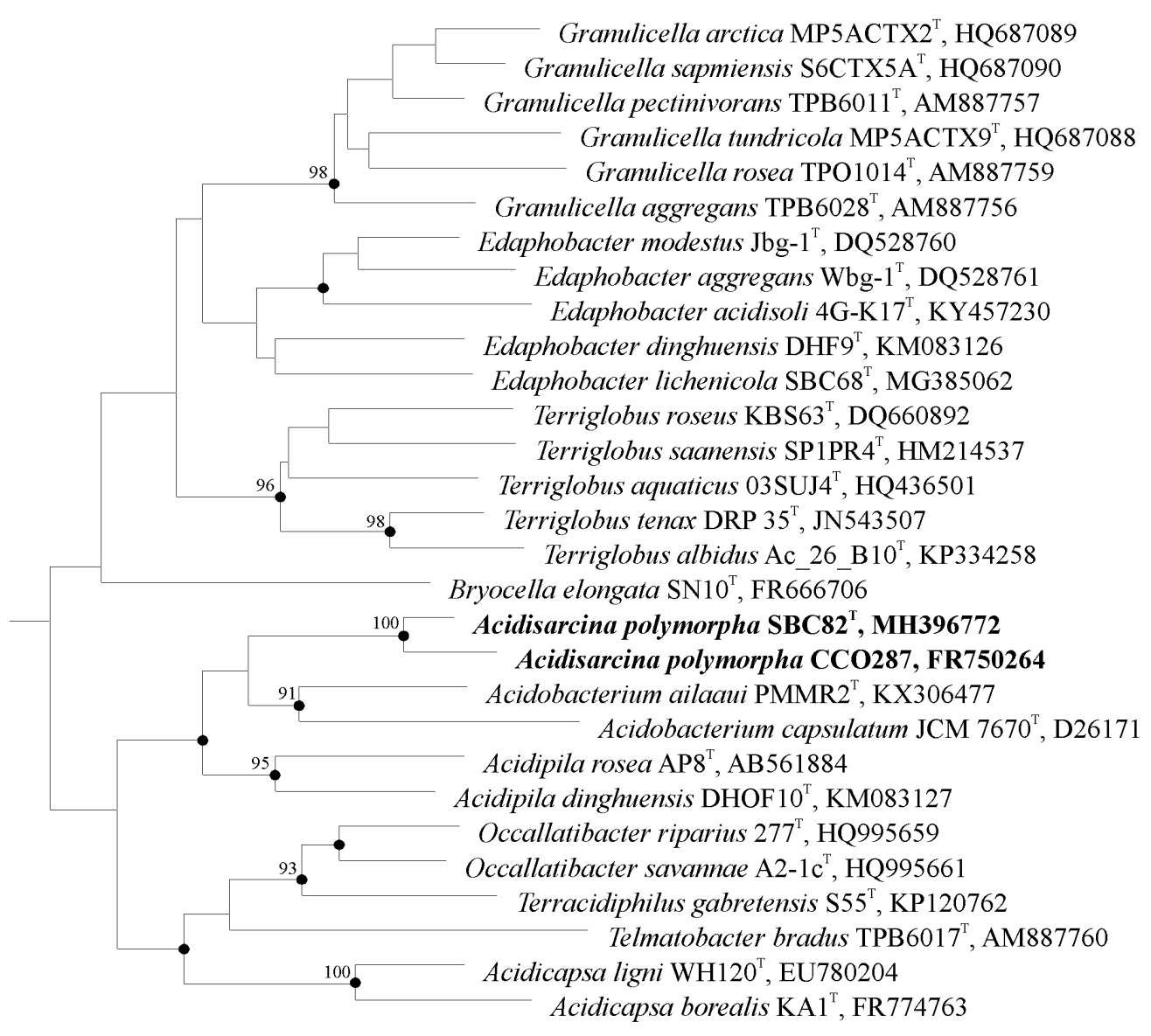

0.05

FIGURE 3 | Unrooted 16S rRNA gene-based neighbor-joining tree showing the phylogenetic relationship of strains SBC82 ${ }^{\top}$ and $\mathrm{CCO} 287$ to representative members of the family Acidobacteriaceae. The tree was calculated based on 1,380 nt positions using the ARB program package (Ludwig et al., 2004). The significance levels of interior branch points obtained in the neighbor-joining analysis were determined by bootstrap analysis (based on 1,000 data resamplings) using PHYLIP (Felsenstein, 1989). Bootstrap values of $>90 \%$ are shown. Black circles indicate that the corresponding nodes were also recovered in the maximum-likelihood and maximum-parsimony trees. Bar, 0.05 substitutions per nucleotide position.

between 4.0 and 7.7 (optimum $\mathrm{pH} 4.8-7.0$ ) and at temperatures between 5 and $36^{\circ} \mathrm{C}$ (optimum at $20-32^{\circ} \mathrm{C}$ ). Sugars and some polysaccharides, like starch and xylan, were the preferred growth substrates. By contrast to strain SBC82 ${ }^{\mathrm{T}}$, strain $\mathrm{CCO} 287$ required supplementation with vitamins (with biotin as a key component) for growth. The complete list of carbon sources utilized by these bacteria and the enzyme activities revealed by the API ZYM test are listed in the species description (see below). Strain $\mathrm{SBC} 82^{\mathrm{T}}$ and CCO287 showed poor growth in micro-oxic conditions but fermentation products were not detected. Growth under strictly anaerobic conditions was not observed. $\mathrm{NaCl}$ inhibited growth at concentrations above $1.5 \%$ (wt/vol).

\section{Growth on Chitin and Chitinolytic Activities}

Given a clearly pronounced response to chitin availability observed for subdivision 1 Acidobacteria in our recent metatranscriptome-based study with acidic peat (Ivanova et al., 2016), we tested the ability of novel isolates to grow on this biopolymer. Since strain CCO287 did not grow well in liquid media, detailed experiments on chitin utilization were performed with strain $\mathrm{SBC} 82^{\mathrm{T}}$. In these tests, chitin was provided either as a sole source of carbon and nitrogen or nitrate was supplemented in addition to chitin to provide an alternative source of nitrogen. Strain $\mathrm{SBC} 82^{\mathrm{T}}$ demonstrated good growth in both types of incubations, although it grew slightly better in the presence of mineral nitrogen (Table 4). Microscopic examination of the respective cultures after 3 weeks of incubation revealed numerous cells of strain $\mathrm{SBC} 82^{\mathrm{T}}$ being attached to micro-particles of amorphous chitin (Figure 4). Cells were highly aggregated and occurred within well-visible saccular chambers (images $2 a-2 c$ in Figure 4). No free-floating cells were observed.

Chitinolytic activities of strain $\mathrm{SBC} 82^{\mathrm{T}}$ grown in chitincontaining medium were detected in cell extracts. Activity was maximal with $\beta$-N-acetylglucosaminidase substrate 
TABLE 2 | Fatty acid composition (\%) released after acid hydrolysis of cell material of strains $\mathrm{SBC}^{\top} 2^{\top}$ and $\mathrm{CCO} 287$.

\begin{tabular}{|c|c|c|}
\hline Fatty acids & $\mathrm{SBC} 2^{\top}$ & CCO287 \\
\hline C14:0 & 0.4 & 0.4 \\
\hline iso-C15:0 & 29.4 & 24.6 \\
\hline$C 16: 1 \omega 7 c$ & 20.4 & 18.5 \\
\hline 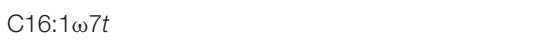 & 0.2 & 1.1 \\
\hline C16:0 & 8.1 & 10.3 \\
\hline 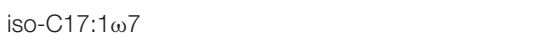 & 2.5 & 2.3 \\
\hline iso-C17:0 & 1.5 & 2.4 \\
\hline ai-C17:0 & 0.7 & 0.5 \\
\hline 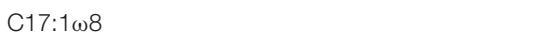 & 0.6 & 0.3 \\
\hline C18:2 & - & 0.4 \\
\hline 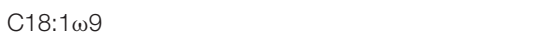 & 2.8 & 5.8 \\
\hline C18:0 & 0.9 & 1.2 \\
\hline C20:0 & 0.2 & 0.6 \\
\hline 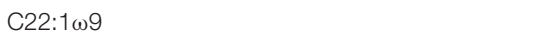 & - & 0.3 \\
\hline $\mathrm{C} 22: 0$ & 1.6 & 1.3 \\
\hline 13,16-Dimethyl octacosanedioic (iso-diabolic acid) & 30.7 & 29.8 \\
\hline
\end{tabular}

Major components (>5\%) are given in bold type. -, not detected.

TABLE 3 | Relative abundances ${ }^{a}$ of intact polar lipids of strains $\mathrm{SBC}^{\top}{ }^{\top}$ and CCO287.

\begin{tabular}{lcc}
\hline IPL $^{\mathbf{b}}$ & SBC82 $^{\mathbf{T}}$ & CC0287 $^{-}$ \\
\hline Unknown IPL (m/z 751) & ++ & + \\
PE & +++ & +++ \\
OL & + & +++ \\
P-hex & ++ & ++
\end{tabular}

The abundance is relative to major peak in the LC/MS base peak chromatogram: +++ , base peak;,$++ 50-100 \%$ of base peak;,$+ 10-50 \%$ of base peak. Note that the mass spectral response factors for different IPL groups can be quite different. ${ }^{b}$ Listed in order of elution: PE, phosphatidyl ethanolamine; OL, ornithine lipid; P-hex, phosphohexose.

TABLE 4 | Cell numbers of SBC82 ${ }^{\top}$ determined by whole-cell hybridizations with Cy3-labeled probe HoAc1402 after 20 days of incubation with chitin as a source of carbon and nitrogen or as a source of carbon.

\begin{tabular}{|c|c|c|c|c|}
\hline \multirow[t]{2}{*}{ Experiment } & \multicolumn{2}{|c|}{ Incubation with chitin } & \multicolumn{2}{|c|}{ Incubation with chitin and $\mathrm{NO}_{3}^{-}$} \\
\hline & +chitin & -chitin & + chitin, $+\mathrm{NO}_{3}^{-}$ & - chitin, $+\mathrm{NO}_{3}^{-}$ \\
\hline I & $182.7 \pm 34.9$ & $0.3 \pm 0.1$ & $228.8 \pm 33.4$ & $0.4 \pm 0.3$ \\
\hline ॥ & $238.2 \pm 25.5$ & $0.4 \pm 0.3$ & $305.8 \pm 35.3$ & $0.7 \pm 0.4$ \\
\hline III & $164.9 \pm 28.8$ & $0.3 \pm 0.1$ & $214.9 \pm 29.0$ & $0.5 \pm 0.2$ \\
\hline
\end{tabular}

The results of three independent incubations (I-III) are shown. Values are numbers of cells $\mathrm{ml}^{-1}\left(\mathrm{~N} \pm\right.$ standard errors $\left.\times 10^{6}\right)$.

4 -MU- $N$-acetyl- $\beta$-D-glucosaminide $\left(32.0 \times 10^{-9} \mathrm{U}_{\text {cell }}{ }^{-1}\right)$, while about 16 -fold lower activity was observed with 4 -MUdiacetyl- $\beta$-D-chitobioside $\left(2.0 \times 10^{-9} \mathrm{U} \mathrm{cell}^{-1}\right)$ and about 100 -times lower activity was recorded with the endochitinase substrate 4-MU- $\beta$-D- $N, N^{\prime}, N^{\prime \prime}$-triacetylchitotriose $\left(0.32 \times 10^{-9}\right.$ $\mathrm{U}_{\text {cell }}^{-1}$ ).

The tests for the presence of chitinolytic capability in strain CCO287 were also positive although only a slow growth was observed. This bacterium was shown to be capable of slow growth on fibrous cellulose in our former study (Pankratov et al., 2011). Strain $\mathrm{SBC} 82^{\mathrm{T}}$ was also tested for growth on cellulose but only a weak growth was recorded. The two isolates differed also with regard to pectin utilization, which was positive for strain CCO287 but negative for strain $\mathrm{SBC} 82^{\mathrm{T}}$. Apparently, these two closely related acidobacteria displayed some clear difference with regard to their hydrolytic capabilities.

\section{Genome Characterization}

To reveal the genetic background of chitinolytic capability, the complete genome sequence was obtained for strain $\mathrm{SBC} 82^{\mathrm{T}}$. It consists of a circular 7,112,011 bp long chromosome with a GC content of $56.8 \%$, and four circular plasmids with lengths of $62,450 \mathrm{bp}, 108,812 \mathrm{bp}, 196,405 \mathrm{bp}$, and $121,048 \mathrm{bp}$. A single 16S23S-5S rRNA operon and 46 tRNA genes were identified. Gene calling and annotation of the genome predicted 7,268 potential protein-coding genes of which 4,227 (58\%) could be functionally assigned.

The value of in silico DNA-DNA hybridization between strain $\mathrm{SBC} 82^{\mathrm{T}}$ and its closest relatives (Figure 3) with determined genome sequences, Acidobacterium ailaaui $\mathrm{PMMR}^{\mathrm{T}}$ and Acidobacterium capsulatum ATCC $51196^{\mathrm{T}}$, was estimated to be about $13 \%$, indicating that strain $\mathrm{SBC} 82^{\mathrm{T}}$ is phylogenetically distant from the closest genus Acidobacterium.

Genome analysis revealed a set of genes encoding a bacterial flagellar apparatus and chemotaxis functions, suggesting that cells of strain $\mathrm{SBC} 82^{\mathrm{T}}$ could be motile under certain growth conditions. The cellulose synthase operon encoding the endoglucanase $B c s Z$, subunit $B c s Q$, the main catalytic glycosyltransferase subunit BcsA fused to the cyclic di-GMP binding subunit $\mathrm{BcsB}$, and the periplasmic subunit $\mathrm{Bcs} C$ were revealed in the genome of $\mathrm{SBC} 82^{\mathrm{T}}$.

Analysis of metabolic pathways revealed that this bacterium is metabolically versatile. The genome of $\mathrm{SBC}^{\mathrm{T}} \mathrm{T}^{\mathrm{T}}$ contains a complete set of genes encoding enzymes of EmbdenMeyerhof and pentose phosphate pathways of carbohydrate metabolism, and the tricarboxylic acids cycle. The pyruvate produced in the glycolysis could be oxidized by pyruvateflavodoxin oxidoreductase, followed by conversion of acetylCoA to acetate with the concomitant production of ATP via a two-step reaction by phosphate acetyltransferase and acetate kinase. Genes for the fermentative production of ethanol and lactate were also present. Cytoplasmic [NiFe] Group 3d: hydrogenase HoxEFUYH could catalyze fermentative NADHdependent production of $\mathrm{H}_{2}$.

Glycogen may be used as a storage polysaccharide as suggested by the presence of genes coding for the key enzymes involved in its synthesis (glucose-1-phosphate adenylyltransferase, glycogen synthase and glycogen branching enzyme). Enzymes for two pathways in the synthesis of another storage carbohydrate, trehalose, were encoded: trehalose synthase, and a pair of maltooligosyl trehalose synthase and maltooligosyl trehalose trehalohydrolase.

Consistently with an aerobic lifestyle of strain $\mathrm{SBC} 82^{\mathrm{T}}$, the major electron transport chain was found, namely $\mathrm{NADH}$ ubiquinone oxidoreductase, membrane-linked succinate 

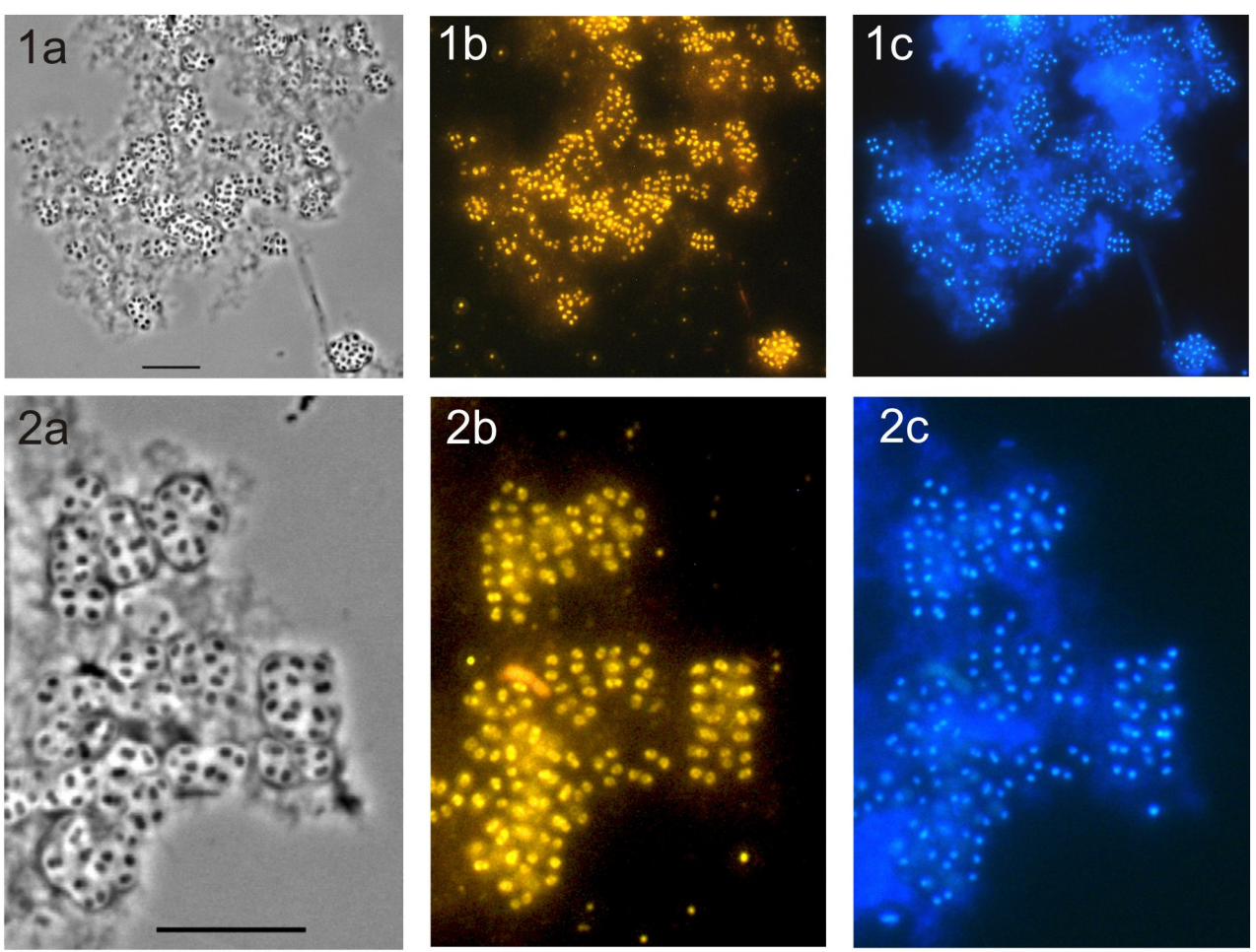

FIGURE 4 | Specific detection of cells of strain $\mathrm{SBC}^{\top} 2^{\top}$ on micro-particles of amorphous chitin used in growth experiments as a sole source of carbon and nitrogen The cultures were pictured after 20 days of incubation. Phase-contrast images (a), the respective epifluorescent micrographs of whole-cell hybridizations with Cy3-labeled probe HoAc1402 (b), and DAPI-staining (c) are shown. Rows (1) and (2) demonstrate different fields of view. Enlarged images in row (2) demonstrate characteristic cellular aggregates of strain $\mathrm{SBC}^{\top}{ }^{\top}$. Bars, $10 \mu \mathrm{m}$.

dehydrogenase, cytochrome $b c_{1}$ complex, cytochrome $c$ oxidase of the $\mathrm{caa}_{3}$ type, and an F-type $\mathrm{H}^{+}$-transporting ATPase. Pathways for dissimilatory reduction of sulfate, Fe(III), nitrate and nitrite were not found. However, strain $\mathrm{SBC} 82^{\mathrm{T}}$ potentially has capacities for anaerobic respiration since its genome encodes three membrane bound molybdopterin oxidoreductases, but specificity of these complexes could not be reliably predicted from the sequence data. The list of genes discussed above is given in Supplementary Table S1.

The search for potential hydrolytic enzymes revealed $>100$ glycoside hydrolases, as well as a wide range of other enzymes involved in transport and metabolism of carbohydrates. The extracellular hydrolysis of chitin could be performed by concerted action of chitinases that hydrolyze chitin to oligo- and disaccharides, and $N$-acetyl-beta-hexosaminidase which further degrades chitooligomers into $\mathrm{N}$-acetylglucosamine (GlcNAc) monomers (Hunt et al., 2008). Genome analysis revealed four endochitinases of GH18 family and three GH20 family $N$-acetyl-beta-hexosaminidases, predicted to contain the N-terminal secretion signals suggesting their extracellular operation (Supplementary Table S2). Transport of GlcNAc and its oligomers across the outer and cytoplasmic membranes could be enabled by carbohydrate-selective porins ( $\mathrm{Li}$ and Roseman, 2004) and $N$-acetylglucosamine-related transporters (NagX), respectively. Two intracellular $\mathrm{GH} 3$ family hexosaminidases and one GH18 family chitinase lacking recognizable N-terminal signal peptide could be responsible for further hydrolysis of short GlcNAc oligomers.

In the cytoplasm, GlcNAc may be phosphorylated to yield GlcNAc-6-P by N-acetylglucosamine kinase. Upon deamination and deacetylation GlcNAc-6-P is converted into fructose-6-P that enters Embden-Meyerhof pathway (Beier and Bertilsson, 2013), while ammonium could be used as a nitrogen source. Similar to truly chitinolytic bacteria such as Chitinispirillum alkaliphilum (Sorokin et al., 2014), the genome of strain SBC82 ${ }^{\mathrm{T}}$ also encodes enzymes responsible for intracellular metabolism of GlcNAc dimers, i.e., chitobiose phosphorylase of GH36 family that can generate GlcNAc and GlcNAc-1-P, and acetylglucosamine-1-Pmutase making GlcNAc-6-P from GlcNAc-1-P.

According to the growth experiments, $\mathrm{SBC} 82^{\mathrm{T}}$ was capable of growth on starch, xylan, and cellulose; the corresponding pathways were also found in the genome (Supplementary Table S2). The presence of four extracellular and five intracellular enzymes related to alpha amylases could enable utilization of starch. The presence of two extracellular endo-1,4- $\beta$-xylanases of GH10 family and three beta-xylosidases is consistent with the ability to grow on xylans. Several signal peptide-containing glycosyl hydrolases could be responsible for extracellular hydrolysis of cellulose. Genome analysis revealed three cellulases of GH5 family, a GH44 family endo-1,4- $\beta$-glucanase, and six $\beta$-glucosidases. The signal peptide-containing GH16 family glycosyl hydrolase could hydrolyse $1,3-\beta$-glucosidic linkages in 
TABLE 5 | Major characteristics that distinguish the genus Acidisarcina from the most closely related genera of the family Acidobacteriaceae.

\begin{tabular}{|c|c|c|c|c|c|c|c|}
\hline Characteristic & Acidisarcina & Acidicapsa & Occallatibacter & Terracidiphilus & Telmatobacter & Acidipila & Acidobacterium \\
\hline Motility & - & V & + & + & + & - & + \\
\hline Capsule & + & + & V & + & - & + & - \\
\hline Pigment & None to light pink & None to pink & None to pink & None & None & Pink & Orange \\
\hline $\begin{array}{l}\text { Anaerobic } \\
\text { growth }\end{array}$ & - & - & - & - & + & - & + \\
\hline $\mathrm{pH}$ range & $4.0-7.7$ & $2.3-7.3$ & $3.5-8.5$ & $3.0-6.0$ & $3.0-7.5$ & $3.0-8.0$ & $3.0-6.0$ \\
\hline pH optimum & $4.8-7.0$ & $4.0-5.0$ & $4.0-6.0$ & $4.0-5.0$ & $4.5-5.0$ & $4.0-4.5$ & ND \\
\hline $\begin{array}{l}\text { Cellulose } \\
\text { degradation }\end{array}$ & + & - & - & + & + & - & - \\
\hline $\begin{array}{l}\text { Major fatty } \\
\text { acids }\end{array}$ & 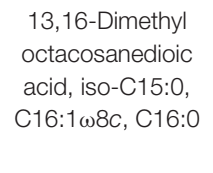 & $\begin{array}{l}\text { 13,16-Dimethyl } \\
\text { octacosanedioic } \\
\text { acid, iso-C15:0 }\end{array}$ & $\begin{array}{c}\text { 13,16-Dimethyl } \\
\text { octacosanedioic } \\
\text { acid, iso-C15:0, } \\
\text { iso-C17:1 } \omega 7 \mathrm{c} \text {, } \\
\text { iso-C17:0 }\end{array}$ & 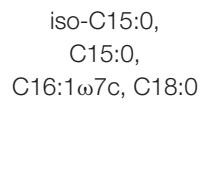 & 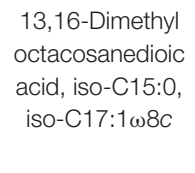 & 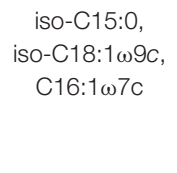 & 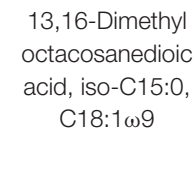 \\
\hline $\begin{array}{l}\mathrm{G}+\mathrm{C} \text { content } \\
(\mathrm{mol} \%)\end{array}$ & 56.8 & $51.7-60.0$ & $58.5-59.9$ & 57.3 & 57.6 & $56.3-59.5$ & $57.2-60.8$ \\
\hline
\end{tabular}

ND, not determined; v. variable.

$1,3-\beta$-D-glucans such as laminarin, consistently with the observed growth of strain $\mathrm{SBC} 82^{\mathrm{T}}$ on this substrate. The GH64 family enzyme could be also responsible for extracellular hydrolysis of $1,3-\beta$-D-glucans.

Although growth on lactate was not observed, the genome of strain SBC82 $2^{\mathrm{T}}$ contains two lactate utilization $l u t A B C$ operons encoding lactate dehydrogenase (Supplementary Table S1). This membrane-associated complex is responsible for oxidation of Llactate to pyruvate in Bacillus subtilis (Chai et al., 2009) and is widespread in bacteria; in SBC $82^{\mathrm{T}}$ this enzyme could drive the oxidation of lactate under aerobic conditions. Another trait that could contribute to adaptation of $\mathrm{SBC} 82^{\mathrm{T}}$ to nutrient limitation is the [NiFe] group $1 \mathrm{~h}$ hydrogenase. Such unidirectional uptake hydrogenases have high affinity and enable scavenging electrons from atmospheric $\mathrm{H}_{2}$ to fuel aerobic respiratory chain when organic electron donors are scarce (Greening et al., 2015).

\section{Metatranscriptome-Based Evidence for the Presence of Hydrolytic Potential}

Since one of the isolates described in this study, strain CCO287, was obtained from a Sphagnum peat used in our recent metatranscriptomic study of biopolymer-degrading microorganisms in peatlands (Ivanova et al., 2016), we made an attempt to re-analyze the SSU rRNA dataset retrieved in this study with the focus on CCO287- and $\mathrm{SBC} 82^{\mathrm{T}}$-like bacteria. The study of Ivanova et al. (2016) assessed the substrate-induced response of peat-inhabiting microorganisms to amendments with cellulose, xylan, pectin and chitin. The $16 \mathrm{~S}$ rRNA reads from CCO287-like and $\mathrm{SBC} 82^{\mathrm{T}}$-like bacteria were sorted out using an identity threshold of $99 \%$ from the sequence sets corresponding to four experimental incubations with different biopolymers and the control incubation without added substrate. This analysis revealed that the pool of $16 \mathrm{~S}$ rRNA reads from $\mathrm{SBC} 82^{\mathrm{T}}$-like and $\mathrm{CCO} 287$-like acidobacteria significantly increased $(P$-value $<0.0001)$ in response to chitin availability (Supplementary Figure S1A). Some weak responses were also observed for both strains in incubations with other polymers, but these were not statistically significant. Similar tendency was observed when this analysis was performed with an identity threshold of 95\% (Supplementary Figure S1B). The pool of $16 \mathrm{~S}$ rRNA reads from Acidisarcina-like bacteria increased from $5 \%$ in the control to $9 \%$ in chitin-amended peat. Metatranscriptome-derived data, therefore, confirm our conclusions regarding the presence of chitinolytic potential in Acidisarcina-like acidobacteria.

Since strains $\mathrm{SBC} 82^{\mathrm{T}}$ and $\mathrm{CCO} 287$ were phylogenetically divergent as well as morphologically and phenotypically distinct from all earlier described Sd1 acidobacteria (Table 5), we propose to classify them as representing a novel genus and species of the family Acidobacteriaceae, Acidisarcina polymorpha gen. nov., sp. nov.

\section{Description of Acidisarcina gen. nov.}

Acidisarcina (A.ci.di.sar.ci'na. N.L. n. acidum, acid; L. fem. n. sarcina, a package, bundle; N.L. fem. n. Acidisarcina, acidophilic package).

Gram-negative, non-spore-forming, highly polymorphic bacteria that occur in pairs, in sarcina-like tetrads, in clusters of 6-8 and more cells. Single cells or short chains of curved cells could also be observed occasionally. In most cases, cells occur inside saccular chambers. Colony color varies from light beige to light pink. Catalase-negative. Aerobic chemoheterotrophs. Capable of growth under micro-oxic conditions. Mild acidophiles and psychrotolerant mesophiles. Sugars are the preferred growth substrates. Capable of hydrolyzing various polysaccharides including chitin and cellulose. Menaquinone- 8 is the major quinone. Major fatty acids are iso- $C_{15: 0}, C_{16: 1} \omega 7 c$, $\mathrm{C}_{16: 0}$ and 13,16-dimethyl octacosanedioic acid. Major polar lipids are phosphatidylethanolamine and phosphohexose; ornithine lipids can also be present. The genus belongs to the family Acidobacteriaceae, the order Acidobacteriales, the class Acidobacteriia. Members of this genus are typical inhabitants 
of acidic soils and peatlands. The type species is Acidisarcina polymorpha.

\section{Description of Acidisarcina polymorpha sp. nov.}

Acidisarcina polymorpha (po.ly.mor'pha. Gr. adj. polys, numerous; Gr. n. morphe, shape. N.L. fem. adj. polymorpha multiform).

The description is as for the genus but with the following additional traits. Cells are 1.4-4.4 $\mu \mathrm{m}$ long and $0.9-1.5 \mu \mathrm{m}$ wide. Carbon sources $(0.05 \%$, w/v) utilized include Darabinose, D-fructose, D-galactose, D-glucose, D-mannose, D-xylose, melezitose, trehalose, D-lactulose, N-acetyl-Dglucosamine, maltose, melibiose, raffinose, dulcitol, and sorbitol. Utilization of lactose, D-leucrose, L-rhamnose, D-ribose, sucrose, salicin, L-sorbose, cellobiose, D-glucuronate, arbutin, inulin, mannitol, methanol, ethanol, pectin, lichenan, and laminarin is variable. Does not utilize D-fucose, pyruvate, acetate, butyrate, capronate, citrate, malate, lactate, formate, D-galacturonate, fumarate, oxalate, propionate, succinate, valerate, adonitol, arabitol, myo-inositol. Hydrolyze esculin, starch, and xylan but not sodium alginate, carboxymethyl-cellulose, chitosan, fucoidan, pullulan. The ability to degrade chitin and cellulose may vary between different strains. The following enzyme activities are present: alkaline and acidic phosphatase, esterase (C4), esterase lipase (C8), leucine-arylamidase, naphtholASBI-phosphohydrolase, $\beta$-glucosidase, valine-arylamidase, $\mathrm{N}$-acetyl- $\beta$-glucosaminidase, $\beta$-galactosidase, weak activities of cystine arylamidase, $\beta$-glucuronidase and lipase (C14). Urease, trypsin, $\alpha$-chymotrypsin, $\alpha$-galactosidase, $\alpha$-glucosidase, $\alpha$ mannosidase, $\alpha$-fucosidase, arginine dihydrolase and protease are absent (API ZYM test). Capable of growth at $\mathrm{pH} 4.0-7.7$ (optimum $\mathrm{pH}$ 4.8-7.0) and at $5-36^{\circ} \mathrm{C}$ (optimum at 20 $32^{\circ} \mathrm{C}$ ). $\mathrm{NaCl}$ inhibits growth at concentrations above $1.5 \%$. Resistant to streptomycin, kanamycin, gentamicin, tetracyclin, lincomycin, ampicillin, chloramphenicol and neomycin, but susceptible to rifampicin and novobiocin. The type strain is strain $\mathrm{SBC} 82^{\mathrm{T}}\left(=\mathrm{KCTC} 82304^{\mathrm{T}}=\mathrm{VKM} \mathrm{B}-3225^{\mathrm{T}}\right)$, which was isolated from acidic soil of lichen covered forested tundra in northern Russia. The DNA G+C content of the type strain is $56.8 \mathrm{~mol} \%$. The GenBank accession numbers for the $16 \mathrm{~S}$ rRNA gene and the genome sequences of strain $\mathrm{SBC}^{2} 2^{\mathrm{T}}$ are MH396772 and CP030840-CP030844 (chromosome and four plasmids), respectively.

\section{DISCUSSION}

The Acidisarcina-like bacteria appear to be common inhabitants of acidic northern soils and peatlands. In lichen-dominated forested tundra sites examined in our study, 16S rRNA gene reads from these microorganisms comprised up to $15 \%$ of all Acidobacteria-affiliated sequences (Figure 1b). In the boreal Sphagnum peat bog examined in our previous study (Ivanova et al., 2016), 16S rRNA fragments from Acidisarcina-like bacteria comprised $\sim 5 \%$ of all acidobacterial reads. Several isolates that could be classified as belonging to the genus Acidisarcina,

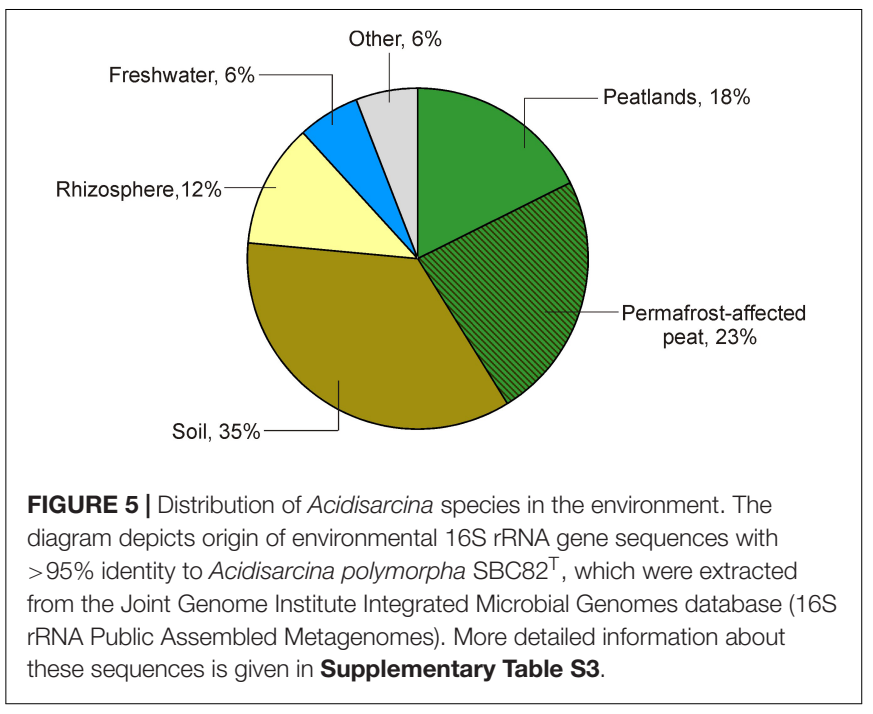

strains K5 and C27 (Acc. No JF490073 and JF490072), were earlier obtained from decomposed thalli of Cladonia sp. collected from the ombrotrophic bog Verkhnee, Karelia (Pankratov, 2012). Acidic woodland soils are also among the habitats colonized by Acidisarcina species since highly similar (97-99\%) 16S rRNA gene sequences (Acc. No HQ598413, HQ598652, HQ598666, HQ598998, HQ599059) were retrieved from several forest sites in Germany (Naether et al., 2012). Notably, a number of Acidisarcina-related $16 \mathrm{~S}$ rRNA gene sequences were obtained from mildly acidic Hawaiian volcanic deposits (Acc. No FJ466263, FJ466272, FJ466284, FJ466322, FJ466337, FJ466355, FJ466443) (Weber and King, 2010) suggesting that these bacteria are among primary colonizers of volcanic deposits. The search for $16 \mathrm{~S}$ rRNA sequences with $>95 \%$ identity to Acidisarcina polymorpha $\mathrm{SBC} 82^{\mathrm{T}}$ in the Joint Genome Institute Integrated Microbial Genomes database (16S rRNA Public Assembled Metagenomes), revealed a total of 68 environmental sequences (>1,000 bp) (Supplementary Table S3). These 16S rRNA sequences were identified world-wide, mostly in peatlands and soils, but also in plant rhizosphere and freshwater habitats (Figure 5).

High environmental fitness and good survival of these bacteria in harsh environments could possibly be explained by a number of traits and specific adaptations. The ultrastructural peculiarity of Acidisarcina is that cells occur within the extracellular compartments appearing as saccular chambers (Figure 2c). Similar structures were earlier described for radiation-resistant pseudomonads (Abashina et al., 2008). These chambers could possibly serve as a structural adaptation with protective function for survival in hostile environments. The exact mechanisms remain to be investigated but the presence of cellulose synthase bcs operon in strain $\mathrm{SBC} 82^{\mathrm{T}}$ suggests its involvement in the synthesis of the chamber envelope produced by these bacteria. Similar bcs operons were found in Acidobacteria species isolated from Arctic tundra soils (Rawat et al., 2012). The genomic potential for trehalose biosynthesis could also contribute to protection of Acidisarcina against cold stress (Freeman et al., 
2010). Protection against the cold could be also enabled by the cold-shock DNA-binding domain proteins, CspA, identified in the genome of strain $\mathrm{SBC} 82^{\mathrm{T}}$. Similar mechanisms of cold protection were found in the $\mathrm{Sd} 1$ acidobacteria isolated from Arctic tundra soils, Granulicella tundricola, Terriglobus saanensis, and Granulicella mallensis (Rawat et al., 2012). An extremely wide repertoire of enzymes involved in degradation of various polymers including chitin, cellulose, and xylan is apparently one of the major reasons behind high environmental relevance of these bacteria. The ability of Acidobacteria to degrade chitin has not received sufficient attention so far.

TABLE 6 | The presence of chitinases and $N$-acetyl-beta-hexosaminidases in Acidobacteria.

\begin{tabular}{l}
\hline $\begin{array}{l}\text { Acidobacterium } \\
\text { (subdivision }\end{array}$ \\
number)
\end{tabular}

number)

\begin{tabular}{|c|c|c|}
\hline $\begin{array}{c}\text { GH18 } \\
\text { family } \\
\text { chitinase }\end{array}$ & $\begin{array}{c}\text { GH19 } \\
\text { family } \\
\text { chitinase }\end{array}$ & $\begin{array}{c}\text { GH20 family } \\
N \text {-acetyl-beta- } \\
\text { hexosaminidases }\end{array}$ \\
\hline
\end{tabular}

\begin{tabular}{|c|c|c|}
\hline $\begin{array}{l}\text { Acidisarcina } \\
\text { polymorpha (1) }\end{array}$ & 5 & - \\
\hline $\begin{array}{l}\text { Acidobacterium } \\
\text { ailaaui (1) }\end{array}$ & 1 & - \\
\hline $\begin{array}{l}\text { Acidobacterium } \\
\text { capsulatum (1) }\end{array}$ & 4 & - \\
\hline $\begin{array}{l}\text { Bryocella elongata } \\
\text { (1) }\end{array}$ & - & - \\
\hline $\begin{array}{l}\text { 'Koribacter } \\
\text { versatilis' (1) }\end{array}$ & 1 & - \\
\hline $\begin{array}{l}\text { 'Solibacter usitatus' } \\
\text { (3) }\end{array}$ & 2 & - \\
\hline $\begin{array}{l}\text { Ca. } \\
\text { Sulfotelmatobacter } \\
\text { kueseliae (1) }\end{array}$ & 1 & - \\
\hline $\begin{array}{l}\text { Ca. } \\
\text { Sulfotelmatomonas } \\
\text { gaucii (1) }\end{array}$ & 2 & - \\
\hline $\begin{array}{l}\text { Edaphobacter } \\
\text { aggregans (1) }\end{array}$ & 5 & - \\
\hline $\begin{array}{l}\text { Granulicella } \\
\text { mallensis (1) }\end{array}$ & 8 & - \\
\hline $\begin{array}{l}\text { Granulicella } \\
\text { pectinivorans (1) }\end{array}$ & 2 & - \\
\hline $\begin{array}{l}\text { Granulicella rosea } \\
\text { (1) }\end{array}$ & 1 & - \\
\hline $\begin{array}{l}\text { Granulicella } \\
\text { tundricola (1) }\end{array}$ & 1 & - \\
\hline $\begin{array}{l}\text { Luteitalea pratensis } \\
\text { (6) }\end{array}$ & 1 & 3 \\
\hline $\begin{array}{l}\text { Silvibacterium } \\
\text { bohemicum (1) }\end{array}$ & 7 & - \\
\hline $\begin{array}{l}\text { Terracidiphilus } \\
\text { gabretensis (1) }\end{array}$ & 3 & - \\
\hline $\begin{array}{l}\text { Terriglobus roseus } \\
\text { (1) }\end{array}$ & 3 & 1 \\
\hline $\begin{array}{l}\text { Terriglobus } \\
\text { saanensis (1) }\end{array}$ & 5 & 1 \\
\hline
\end{tabular}

3

3

3

4

2

2

4

6

7

3

$-$

3

3

3
Much of the previously available evidence for the presence of chitinolytic capabilities in Acidobacteria originated from the genome analyses of these microorganisms (Ward et al., 2009; Rawat et al., 2012; Kielak et al., 2016). Our search also revealed the presence of numerous chitinase- and $N$-acetyl-betahexosaminidase-encoding genes in genomes and metagenomes of many Sd1 Acidobacteria as well as in Sd3 member 'Solibacter usitatus' and in Sd6 member Luteitalea pratensis (Table 6). The highest numbers of GH18 chitinases were revealed in Granulicella mallensis MP5ACTX8 ${ }^{\mathrm{T}}$ (8), Silvibacterium bohemicum $\mathrm{S} 15^{\mathrm{T}}$ (7) and Terriglobus saanensis $\mathrm{SP} 1 \mathrm{PR} 4^{\mathrm{T}}$ (6). Of these bacteria, only Silvibacterium bohemicum $\mathrm{S}^{\mathrm{T}}{ }^{\mathrm{T}}$ was characterized as being capable of growth on colloidal chitin (Lladó et al., 2016). Few other taxonomic descriptions of acidobacteria also list chitin among the potential growth substrates (Foesel et al., 2013; GarcíaFraile et al., 2015). All of these studies, however, simply report the results of the respective growth tests on chitin as being positive and do not provide any further information. In case of Silvibacterium bohemicum $\mathrm{S} 15^{\mathrm{T}}$ and Terracidiphilus gabretensis $\mathrm{S} 55^{\mathrm{T}}$ the activity of $\mathrm{N}$-acetylglucosaminidase was detected and referred as one of the proofs for growth on chitin. The most apparent reason for this lack of information is slow growth of all earlier described Acidobacteria on chitin. The bacterium examined in our study, strain $\mathrm{SBC} 82^{\mathrm{T}}$, was isolated from a habitat enriched with fungal-derived chitin, i.e., an organic soil layer underlying lichen cover. Although Acidobacteria are not recognized as an important component of the lichen-associated microbiome (Cernava et al., 2017), decaying lichen thalli or underlying organic layers are abundantly colonized by these bacteria (Pankratov, 2012).

Strains $\mathrm{SBC} 82^{\mathrm{T}}$ and CCO287 exemplify the situation with two members of the same species displaying difference with regard to their hydrolytic capabilities. The first bacterium was isolated from a chitin-rich habitat and grew well with chitin, while only a poor growth was observed on cellulose. The second isolate was obtained from Sphagnum-derived peat and displayed weak chitinolytic capabilities but demonstrated consistent growth on cellulose. These results show that hydrolytic activities may vary within members of the same species and highlight the importance of describing a bacterial species based on characterization of several independent isolates, preferably obtained from different habitats.

It has been suggested that acidobacteria become particularly important in the niches where other well-known and fast-acting bacterial decomposers, such as Firmicutes and Bacteroidetes, are absent or numerically insignificant (Pankratov et al., 2011). This is the case in ombrotrophic boreal peat bogs, lichendominated acidic soils and peatlands of tundra. In these habitats, Acidobacteria become one of the major groups of hydrolytic bacteria with Acidisarcina as one of the numerically abundant bacterial populations. The genome encoded ability to feed on a wide range of complex carbohydrates is one of the key traits of these acidobacteria. The ability to utilize the nitrogen-containing polymer chitin gives these bacteria an additional ecological advantage in nitrogen-depleted acidic northern wetlands and soils. 


\section{AUTHOR CONTRIBUTIONS}

SD and SB designed the study. AI examined Acidobacteria diversity in soil samples and analyzed metatranscriptome-derived data. SB and TP obtained isolates of acidobacteria and performed growth experiments. $\mathrm{NR}, \mathrm{AB}$, and $\mathrm{AM}$ obtained, annotated, and analyzed the genome sequence. AR performed hydrolytic activity assays. JSD performed chemotaxonomic analyses. SD and NR wrote the manuscript.

\section{FUNDING}

This study was supported by the Russian Science Foundation (Project No. 16-14-10210). TP was supported by the Russian Foundation for Basic Research (Project No. 16-04-00966a). JSD was supported by the Soehngen Institute for Anaerobic

\section{REFERENCES}

Abashina, T. N., Suzina, N. E., Akimov, V. N., Duda, V. I., and Vainshtein, M. B. (2008). Extracellular communal structures: saccular chambers in radiationresistant pseudomonads. Microbiology 77, 115-117. doi: 10.1007/s11021-0081017-2

Barns, S. M., Takala, S. L., and Kuske, C. R. (1999). Wide distribution and diversity of members of the bacterial kingdom Acidobacterium in the environment. Appl. Environ. Microbiol. 65, 1731-1737.

Beier, S., and Bertilsson, S. (2013). Bacterial chitin degradation - mechanisms and ecophysiological strategies. Front. Microbiol. 4:149. doi: 10.3389/fmicb.2013. 00149

Brettin, T., Davis, J. J., Disz, T., Edwards, R. A., Gerdes, S., Olsen, G. J., et al. (2015). RASTtk: a modular and extensible implementation of the RAST algorithm for building custom annotation pipelines and annotating batches of genomes. Sci. Rep. 5:8365. doi: 10.1038/srep08365

Camacho, C., Coulouris, G., Avagyan, V., Ma, N., Papadopoulos, J., Bealer, K., et al. (2009). BLAST+: architecture and applications. BMC Bioinformatics 10:421. doi: 10.1186/1471-2105-10-421

Cao, M. D., Nguyen, S. H., Ganesamoorthy, D., Elliott, A. G., Cooper, M. A., and Coin, L. J. M. (2017). Scaffolding and completing genome assemblies in real-time with nanopore sequencing. Nat. Commun. 8:14515. doi: 10.1038/ ncomms 14515

Caporaso, J. G., Lauber, C. L., Walters, W. A., Berg-lyons, D., Lozupone, C. A., Turnbaugh, P. J., et al. (2010). Global patterns of $16 \mathrm{~S}$ rRNA diversity at a depth of millions of sequences per sample. Proc. Natl. Acad. Sci. U.S.A. 108, 4516-4522. doi: 10.1073/pnas.1000080107

Caporaso, J., Kuczynski, J., and Stombaugh, J. (2010). QIIME allows analysis of high-throughput community sequencing data. Nat. Methods 7, 335-336. doi: 10.1038/nmeth0510-335

Cernava, T., Erlacher, A., Aschenbrenner, I. A., Krug, L., Lassek, C., Riedel, K., et al. (2017). Deciphering functional diversification within the lichen microbiota by meta-omics. Microbiome 5:82. doi: 10.1186/s40168-017-0303-5

Chai, Y., Kolter, R., and Losick, R. (2009). A widely conserved gene cluster required for lactate utilization in Bacillus subtilis and its involvement in biofilm formation. J. Bacteriol. 191, 2423-2430. doi: 10.1128/JB.01464-08

Collins, M. D. (1985). Analysis of isoprenoid quinones. Methods Microbiol. 18, 329-366. doi: 10.1016/S0580-9517(08)70480-X

Dedysh, S. N., Derakshani, M., and Liesack, W. (2001). Detection and enumeration of methanotrophs in acidic Sphagnum peat by 16S rRNA fluorescence in situ hybridization, including the use of newly developed oligonucleotide probes for Methylocella palustris. Appl. Environ. Microbiol. 67, 4850-4857. doi: 10.1128/ AEM.67.10.4850-4857.2001

Dedysh, S. N., and Sinninghe Damsté, J. S. (2018). Acidobacteria. Chichester: John Wiley \& Sons, Ltd. 1-10. doi: 10.1002/9780470015902.a0027685
Microbiology (SIAM) through a gravitation grant (024.002.002) from the Dutch Ministry for Education, Culture and Science.

\section{ACKNOWLEDGMENTS}

The authors thank Natalia E. Suzina (Skryabin Institute for Biochemistry and Physiology of Microorganisms) for electron microscopy and W. Irene C. Rijpstra (NIOZ Royal Netherlands Institute for Sea Research) for lipid analyses.

\section{SUPPLEMENTARY MATERIAL}

The Supplementary Material for this article can be found online at: https://www.frontiersin.org/articles/10.3389/fmicb. 2018.02775/full\#supplementary-material

Eichorst, S. A., Kuske, C. R., and Schmidt, T. M. (2011). Influence of plant polymers on the distribution and cultivation of bacteria in the phylum Acidobacteria. Appl. Environ. Microbiol. 77, 586-596. doi: 10.1128/AEM.01080-10

Eichorst, S. A., Trojan, D., Roux, S., Herbold, C., Rattei, T., and Woebken, D. (2018). Genomic insights into the Acidobacteria reveal strategies for their success in terrestrial environments. Environ. Microbiol. 20, 1041-1063. doi: 10.1111/1462-2920.14043

Felsenstein, J. (1989). Phylip: phylogeny inference package (version 3.2). Cladistics 5, 164-166. doi: 10.1111/j.1096-0031.1989.tb00562.x

Foesel, B. U., Nägele, V., Naether, A., Wüst, P. K., Weinert, J., Bonkowski, M., et al. (2014). Determinants of Acidobacteria activity inferred from the relative abundances of 16S rRNA transcripts in German grassland and forest soils. Environ. Microbiol. 16, 658-675. doi: 10.1111/1462-2920.12162

Foesel, B. U., Rohde, M., and Overmann, J. (2013). Blastocatella fastidiosa gen. nov., sp. nov., isolated from semiarid savanna soil - the first described species of Acidobacteria subdivision 4. Syst. Appl. Microbiol. 36, 82-89. doi: 10.1016/j. syapm.2012.11.002

Freeman, B. C., Chen, C., and Beattie, G. A. (2010). Identification of the trehalose biosynthetic loci of Pseudomonas syringae and their contribution to fitness in the phyllosphere. Environ. Microbiol. 12, 1486-1497. doi: 10.1111/j.1462-2920. 2010.02171.x

García-Fraile, P., Benada, O., Cajthaml, T., Baldrian, P., and Lladó, S. (2015). Terracidiphilus gabretensis gen. nov., sp. nov.: an abundant and active forest soil Acidobacteria important in organic matter transformation. Appl. Environ. Microbiol. 82, 560-569. doi: 10.1128/AEM.03353-15

Gerhardt, P. (1981). Manual of Methods for General Bacteriology. Washington, DC: American Society for Microbiology.

Grabherr, M. G., Haas, B. J., Yassour, M., Levin, J. Z., Thompson, D. A., Amit, I., et al. (2011). Full-length transcriptome assembly from RNA-Seq data without a reference genome. Nat. Biotechnol. 29, 644-652. doi: 10.1038/nbt. 1883

Greening, C., Carere, C. R., Rushton-Green, R., Harold, L. K., Hards, K., Taylor, M. C., et al. (2015). Persistence of the dominant soil phylum Acidobacteria by trace gas scavenging. Proc. Natl. Acad. Sci. U.S.A. 112, 10497-10502. doi: 10.1073/pnas.1508385112

Hunt, D. E., Gevers, D., Vahora, N. M., and Polz, M. F. (2008). Conservation of the chitin utilization pathway in the Vibrionaceae. Appl. Environ. Microbiol. 74, 44-51. doi: 10.1128/AEM.01412-07

Ivanova, A. A., Wegner, C. E., Kim, Y., Liesack, W., and Dedysh, S. N. (2016). Identification of microbial populations driving biopolymer degradation in acidic peatlands by metatranscriptomic analysis. Mol. Ecol. 25, 4818-4835. doi: $10.1111 /$ mec. 13806

Janssen, P. H. (2006). Identifying the dominant soil bacterial taxa in libraries of 16S rRNA and 16S rRNA genes. Appl. Environ. Microbiol. 72, 1719-1728. doi: 10.1128/AEM.72.3.1719-1728.2006 
Jones, R. T., Robeson, M. S., Lauber, C. L., Hamady, M., Knight, R., and Fierer, N. (2009). A comprehensive survey of soil acidobacterial diversity using pyrosequencing and clone library analyses. ISME J. 3, 442-453. doi: 10.1038/ ismej. 2008.127

Juottonen, H., Eiler, A., Biasi, C., Tuittila, E. S., Yrjälä, K., and Fritze, H. (2017). Distinct anaerobic bacterial consumers of cellobiose-derived carbon in boreal fens with different $\mathrm{CO}_{2} / \mathrm{CH} 4$ production ratios. Appl. Environ. Microbiol. 8:e02533-16. doi: 10.1128/AEM.02533-16

Juretschko, S., Loy, A., Lehner, A., and Wagner, M. (2002). The microbial community composition of a nitrifying-denitrifying activated sludge from an industrial sewage treatment plant analyzed by the full-cycle rRNA approach. Syst. Appl. Microbiol. 25, 84-99. doi: 10.1078/0723-2020-00093

Kielak, A. M., Barreto, C. C., Kowalchuk, G. A., van Veen, J. A., and Kuramae, E. E. (2016). The ecology of Acidobacteria: moving beyond genes and genomes. Front. Microbiol. 7:744. doi: 10.3389/fmicb.2016.00744

Koren, S., Walenz, B. P., Berlin, K., Miller, J. R., Bergman, N. H., and Phillippy, A. M. (2017). Canu: scalable and accurate long-read assembly via adaptive $\mathrm{k}$ mer weighting and repeat separation. Genome Res. 27, 722-736. doi: 10.1101/ gr.215087.116

Kublanov, I. V., Perevalova, A. A., Slobodkina, G. B., Lebedinsky, A. V., Bidzhieva, S. K., Kolganova, T. V., et al. (2009). Biodiversity of thermophiiic prokaryotes with hydrolytic activities in hot springs of uzon caldera, kamchatka (Russia). Appl. Environ. Microbiol. 75, 286-291. doi: 10.1128/AEM.00607-08

Langmead, B., and Salzberg, S. L. (2012). Fast gapped-read alignment with Bowtie 2. Nat. Methods 9, 357-359. doi: 10.1038/nmeth.1923

Lauber, C. L., Hamady, M., Knight, R., and Fierer, N. (2009). Pyrosequencing-based assessment of soil $\mathrm{pH}$ as a predictor of soil bacterial community structure at the continental scale. Appl. Environ. Microbiol. 75, 5111-5120. doi: 10.1128/AEM. 00335-09

Lee, S. H., Ka, J. O., and Cho, J. C. (2008). Members of the phylum Acidobacteria are dominant and metabolically active in rhizosphere soil. FEMS Microbiol. Lett. 285, 263-269. doi: 10.1111/j.1574-6968.2008.01232.x

Li, X., and Roseman, S. (2004). The chitinolytic cascade in Vibrios is regulated by chitin oligosaccharides and a two-component chitin catabolic sensor/kinase. Proc. Natl. Acad. Sci. U.S.A. 101, 627-631. doi: 10.1073/pnas.0307645100

Lladó, S., Benada, O., Cajthaml, T., Baldrian, P., and García-Fraile, P. (2016). Silvibacterium bohemicum gen. nov. sp. nov., an acidobacterium isolated from coniferous soil in the Bohemian Forest National Park. Syst. Appl. Microbiol. 39, 14-19. doi: 10.1016/j.syapm.2015.12.005

Ludwig, W., Bauer, S. H., Bauer, M., Held, I., Kirchhof, G., Schulze, R., et al. (1997). Detection and in situ identification of representatives of a widely distributed new bacterial phylum. FEMS Microbiol. Lett. 153, 181-190. doi: 10.1016/S03781097(97)00256-5

Ludwig, W., Strunk, O., Westram, R., Richter, L., Meier, H., Yadhukumar, A., et al. (2004). ARB: a software environment for sequence data. Nucleic Acids Res. 32, 1363-1371. doi: 10.1093/nar/gkh293

Meier-Kolthoff, J. P., Auch, A. F., Klenk, H.-P., and Göker, M. (2013). Genome sequence-based species delimitation with confidence intervals and improved distance functions. BMC Bioinformatics 14:60. doi: 10.1186/14712105-14-60

Moore, E. K., Hopmans, E. C., Rijpstra, W. I. C., Villanueva, L., Dedysh, S. N., Kulichevskaya, I. S., et al. (2013). Novel mono-, di-, and trimethylornithine membrane lipids in northern wetland planctomycetes. Appl. Environ. Microbiol. 79, 6874-6884. doi: 10.1128/AEM.0216913

Naether, A., Foesel, B. U., Naegele, V., Wüst, P. K., Weinert, J., Bonkowski, M., et al. (2012). Environmental factors affect acidobacterial communities below the subgroup level in grassland and forest soils. Appl. Environ. Microbiol. 78, 7398-7406. doi: 10.1128/AEM.01325-12

Pankratov, T. A. (2012). Acidobacteria in microbial communities of the bog and tundra lichens. Microbiology 81, 51-58. doi: 10.1134/S0026261711060166

Pankratov, T. A., Ivanova, A. O., Dedysh, S. N., and Liesack, W. (2011). Bacterial populations and environmental factors controlling cellulose degradation in an acidic Sphagnum peat. Environ. Microbiol. 13, 1800-1814. doi: 10.1111/j.14622920.2011.02491.x

Pankratov, T. A., Kirsanova, L. A., Kaparullina, E. N., Kevbrin, V. V., and Dedysh, S. N. (2012). Telmatobacter bradus gen. nov., sp. nov., a cellulolytic facultative anaerobe from subdivision 1 of the Acidobacteria, and emended description of
Acidobacterium capsulatum Kishimoto et al. 1991. Int. J. Syst. Evol. Microbiol. 62, 430-437. doi: 10.1099/ijs.0.029629-0

Pruesse, E., Quast, C., Knittel, K., Fuchs, B. M., Ludwig, W., Peplies, J., et al. (2007). SILVA: a comprehensive online resource for quality checked and aligned ribosomal RNA sequence data compatible with ARB. Nucleic Acids Res. 35, 7188-7196. doi: 10.1093/nar/gkm864

Quast, C., Pruesse, E., Yilmaz, P., Gerken, J., Schweer, T., Yarza, P., et al. (2013). The SILVA ribosomal RNA gene database project: improved data processing and web-based tools. Nucleic Acids Res. 41, D590-D596. doi: 10.1093/nar/ gks1219

Rawat, S. R., Männistö, M. K., Bromberg, Y., and Häggblom, M. M. (2012). Comparative genomic and physiological analysis provides insights into the role of Acidobacteria in organic carbon utilization in Arctic tundra soils. FEMS Microbiol. Ecol. 82, 341-355. doi: 10.1111/j.1574-6941.2012. 01381.x

Reynolds, E. S. (1963). The use of lead citrate at high $\mathrm{pH}$ as an electron-opaque stain in electron microscopy. J. Cell Biol. 17, 208-212.

Schmidt, O., Horn, M. A., Kolb, S., and Drake, H. L. (2014). Temperature impacts differentially on the methanogenic food web of cellulose-supplemented peatland soil. Environ. Microbiol. 17, 720-734. doi: 10.1111/1462-2920.12507

Serkebaeva, Y. M., Kim, Y., Liesack, W., and Dedysh, S. N. (2013). Pyrosequencingbased assessment of the bacteria diversity in surface and subsurface peat layers of a northern wetland, with focus on poorly studied phyla and candidate divisions. PLoS One 8:e63994. doi: 10.1371/journal.pone.006 3994

Sinninghe Damsté, J. S., Rijpstra, W. I. C., Hopmans, E. C., Weijers, J. W. H., Foesel, B. U., Overmann, J., et al. (2011). 13,16-Dimethyl octacosanedioic acid (iso-diabolic acid), a common membrane-spanning lipid of Acidobacteria subdivisions 1 and 3. Appl. Environ. Microbiol. 77, 4147-4154. doi: 10.1128/ AEM.00466-11

Sorokin, D. Y., Gumerov, V. M., Rakitin, A. L., Beletsky, A. V., Damsté, J. S. S., Muyzer, G., et al. (2014). Genome analysis of Chitinivibrio alkaliphilus gen. nov., sp. nov., a novel extremely haloalkaliphilic anaerobic chitinolytic bacterium from the candidate phylum Termite Group 3. Environ. Microbiol. 16, 15491565. doi: 10.1111/1462-2920.12284

Stevenson, B. S., Eichorst, S. A., Wertz, J. T., Schmidt, T. M., and Breznak, J. A. (2004). New strategies for cultivation and detection of previously uncultured microbes. Appl. Environ. Microbiol. 70, 4748-4755. doi: 10.1128/AEM.70.8. 4748-4755.2004

Štursová, M., Žifčáková, L., Leigh, M. B., Burgess, R., and Baldrian, P. (2012). Cellulose utilization in forest litter and soil: identification of bacterial and fungal decomposers. FEMS Microbiol. Ecol. 80, 735-746. doi: 10.1111/j.1574-6941. 2012.01343.x

Walker, B. J., Abeel, T., Shea, T., Priest, M., Abouelliel, A., Sakthikumar, S., et al. (2014). Pilon: an integrated tool for comprehensive microbial variant detection and genome assembly improvement. PLoS One 9:e112963. doi: 10.1371/journal. pone.0112963

Ward, N. L., Challacombe, J. F., Janssen, P. H., Henrissat, B., Coutinho, P. M., $\mathrm{Wu}, \mathrm{M}$., et al. (2009). Three genomes from the phylum Acidobacteria provide insight into the lifestyles of these microorganisms in soils. Appl. Environ. Microbiol. 75, 2046-2056. doi: 10.1128/AEM.02294-08

Weber, C. F., and King, G. M. (2010). Distribution and diversity of carbon monoxide-oxidizing bacteria and bulk bacterial communities across a succession gradient on a Hawaiian volcanic deposit. Environ. Microbiol. 12, 1855-1867. doi: 10.1111/j.1462-2920.2010.02190.x

Conflict of Interest Statement: The authors declare that the research was conducted in the absence of any commercial or financial relationships that could be construed as a potential conflict of interest.

Copyright (C) 2018 Belova, Ravin, Pankratov, Rakitin, Ivanova, Beletsky, Mardanov, Sinninghe Damsté and Dedysh. This is an open-access article distributed under the terms of the Creative Commons Attribution License (CC BY). The use, distribution or reproduction in other forums is permitted, provided the original author(s) and the copyright owner(s) are credited and that the original publication in this journal is cited, in accordance with accepted academic practice. No use, distribution or reproduction is permitted which does not comply with these terms. 